\title{
Analysis of Trends in Drought with the Non-Parametric Approach in Vietnam: A Case Study in Ninh Thuan Province
}

\author{
Nguyen Hoang Tuan*, Truong Thanh Canh \\ University of Science, VNU.HCM, Ho Chi Minh City, Vietnam \\ Email: *nhtuansg@gmail.com
}

How to cite this paper: Tuan, N. H., \& Canh, T. T. (2021). Analysis of Trends in Drought with the Non-Parametric Approach in Vietnam: A Case Study in Ninh Thuan Province. American Journal of Climate Change, 10, 51-84.

https://doi.org/10.4236/ajcc.2021.101004

Received: November 9, 2020

Accepted: March 22, 2021

Published: March 25, 2021

Copyright $\odot 2021$ by author(s) and Scientific Research Publishing Inc. This work is licensed under the Creative Commons Attribution International License (CC BY 4.0).

http://creativecommons.org/licenses/by/4.0/

(c) (i) Open Access

\begin{abstract}
A quantitative study was used in the study of the tendency to change drought indicators in Vietnam through the Ninh Thuan province case study. The research data are temperature and precipitation data of 11 stations from 1986 to 2016 inside and outside Ninh Thuan province. To do the research, the author uses a non-parametric analysis method and the drought index calculation method. Specifically, with the non-parametric method, the author uses the analysis, Mann-Kendall (MK) and Theil-Sen (Sen's slope), and to analyze drought, the author uses the Standardized Precipitation Index (SPI) and the Moisture Index (MI). Two Softwares calculated in this study are ProUCL 5.1 and MAKENSEN 1.0 by the US Environmental Protection Agency and Finnish Meteorological Institute. The calculation results show that meteorological drought will decrease in the future with areas such as Phan Rang, Song Pha, Quan The, Ba Thap tend to increase very clearly, while Tam My and Nhi Ha tend to increase very clearly short. With the agricultural drought, the average MI results increased 0.013 per year, of which Song Pha station tended to increase the highest with 0.03 per year and lower with Nhi Ha with 0.001 per year. The forecast results also show that by the end of the 21st century, the SPI tends to decrease with SPI 1 being -0.68 , SPI 3 being -0.40 , SPI 6 being -0.25 , SPI 12 is 0.42 . Along with that is the forecast that the MI index will increase 0.013 per year to 2035 , the MI index is 0.93 , in 2050 it is 1.13 , in 2075 it will be 1.46 , and by 2100 it is 1.79 . Research results will be used in policymaking, environmental resources management agencies, and researchers to develop and study solutions to adapt and mitigate drought in the context of variable climate change.
\end{abstract}

\section{Keywords}

Drought, Mann-Kendall, Sen's Slope, Non-Parametric 


\section{Introduction}

Drought can be considered an expensive natural disaster in the world (Esfahanian et al., 2017); this is an uncontrollable extreme phenomenon (Correia, 2007), it affects regions and the Earth (Blain, 2012; Ding et al., 2010; Svoboda et al., 2015). Studies also show that drought impacts politics, as it can affect and spread over a region of countries in the world (UN Water, 2015b). During the current period, in the face of climate change, drought is one of the dangerous natural disasters appearing more and more in the world (Lake, 2011), without a fixed boundary (UN Water, 2015a), and an escalating phenomenon to the dangerous level of nature (Gillette, 1950; Govorushko, 2012; Prud'Homme, 2011; UN Water, 2015a; WMO, 2014), and varies with each other region (Bordi \& Sutera, 2007; Brewer \& Heim Jr., 2011).

Droughts have a significant impact on economic, social, and environmental activities around the world (Ding et al., 2010; Lake, 2011; Wilhite \& Glantz, 1987), whose direct and indirect impacts continued (Jenkins, 2011; Jeyaseelan, 2003), drought affects livelihoods, food security, and environmental quality (Bordi \& Sutera, 2007; GSA, 2006; Jenkins, 2011; Tadesse et al., 2008; Tannehill, 1947; UN Water, 2015b; UNDP, 2012; UNESCO, 2014; UNISDR, 2009; WMO, 2014). In fact, between 1970 and 2000, the rate of drought increased to $30 \%$ globally (Dai et al., 2004), causing significant damage to the world economy on 1960 , drought caused up to $\$ 40$ billion; in the 1980s, it reached $\$ 120$ billion (Domeisen, 1995). According to statistics, today on Earth, $40 \%-45 \%$ of the area is drought, where one-third of the population lives globally (Govorushko, 2012), African countries, India, North America, China, Russia (former the Soviet Union), Australia, and Western Europe are strongly affected by drought and are continually affected (Wilhite \& Glantz, 1987). In Australia, the rate of drought increased by $20 \%$ annually during 1993-2006 and severely affected the country (Henry et al., 2007). Research history shows that the losses amounted to $\$ 3$ billion (Abares, 2012). In Africa, drought directly affects food security and commodity prices of countries (AghaKouchak, 2014); it accounts for $20 \%$ of all-natural disasters (CRED, 2006); for example, drought killed one million people among $\$ 8$ million, affected and caused the loss of $90 \%$ livestock (Allaby et al., 2003). In European countries, the total economic loss over 30 years for the EU countries is at least $€ 100$ billion (Correia, 2007). In agricultural production, drought has made productivity, food output decreased and affected livelihoods; in Spain, grain production decreased by $42 \%$, losing nearly $€ 8$ billion (Correia, 2007). The United States caused a loss of over 12 billion USD (AghaKouchak, 2014); in California, the agricultural value fell to $\$ 50.3$ billion in 2013 (Cooley et al., 2015), with more than 17,000 unemployed people (Koba, 2014), estimated average annual damage is $\$ 6$ - $\$ 8$ billion (Wilhite, 2000). In the United States, drought is considered a recurring natural disaster (Herweijer et al., 2007).

\section{The Study Area}

Ninh Thuan $\left(11^{\circ} 33^{\prime} 56^{\prime \prime} \mathrm{N} \& 108^{\circ} 59^{\prime} 25^{\prime \prime} \mathrm{E}\right)$ is a coastal province in the South Cen- 
tral Coast of Vietnam. The North borders Khanh Hoa province, the South borders Binh Thuan province, the Western borders Lam Dong, and the eastern border with the East Sea (Figure 1).

Ninh Thuan a province in a tropical monsoon climate area; there is a tropical savanna climate in Phan Rang with the features of drought, hot weather, much wind, and rapid evaporation (Thao et al., 2018). Ninh Thuan is one of the provinces most affected by drought in Vietnam (Ngo Dinh Tuan \& Ngo Le An, 2016; Nguyễn Đinh Tuấn et al., 2012) and this is also a region at risk of desertification and severe land resource degradation in Viet Nam (Ngo Dinh Tuan \& Ngo Le An, 2016; Nguyễn Hông Trường, 2008). Ninh Thuan is a province with quite severe hydro-meteorological conditions, the average rainfall for many years in Ninh Thuan is all achieved about $750 \mathrm{~mm}$ per year, with very high hours of sunshine of about 2700 - 2800 hours per year, the results of the Gausen index in Phan Rang $\mathrm{Kx}=250$ show that this is a heavy dry area (Nguyễn Đình Vượng \& Huỳnh Ngọc Tuyên, 2012). The density of rivers in Ninh Thuan is relatively low, from 0.1 to $0.2 \mathrm{~km}$ per $\mathrm{km}^{2}$; rivers are often short and steep (Nguyễn Hồng Trường, 2008). There were many severe droughts in 1988, 1993, 1998, 2001, $2002,2004,2005$, causing significant damage to the agricultural sector and socio-economic activities. The study selected Ninh Thuan as a trend research model because this is the drought center of Vietnam, where droughts frequently occur, and this is also a sample of drought research that is representative of Vietnam and regions of drought in the world.

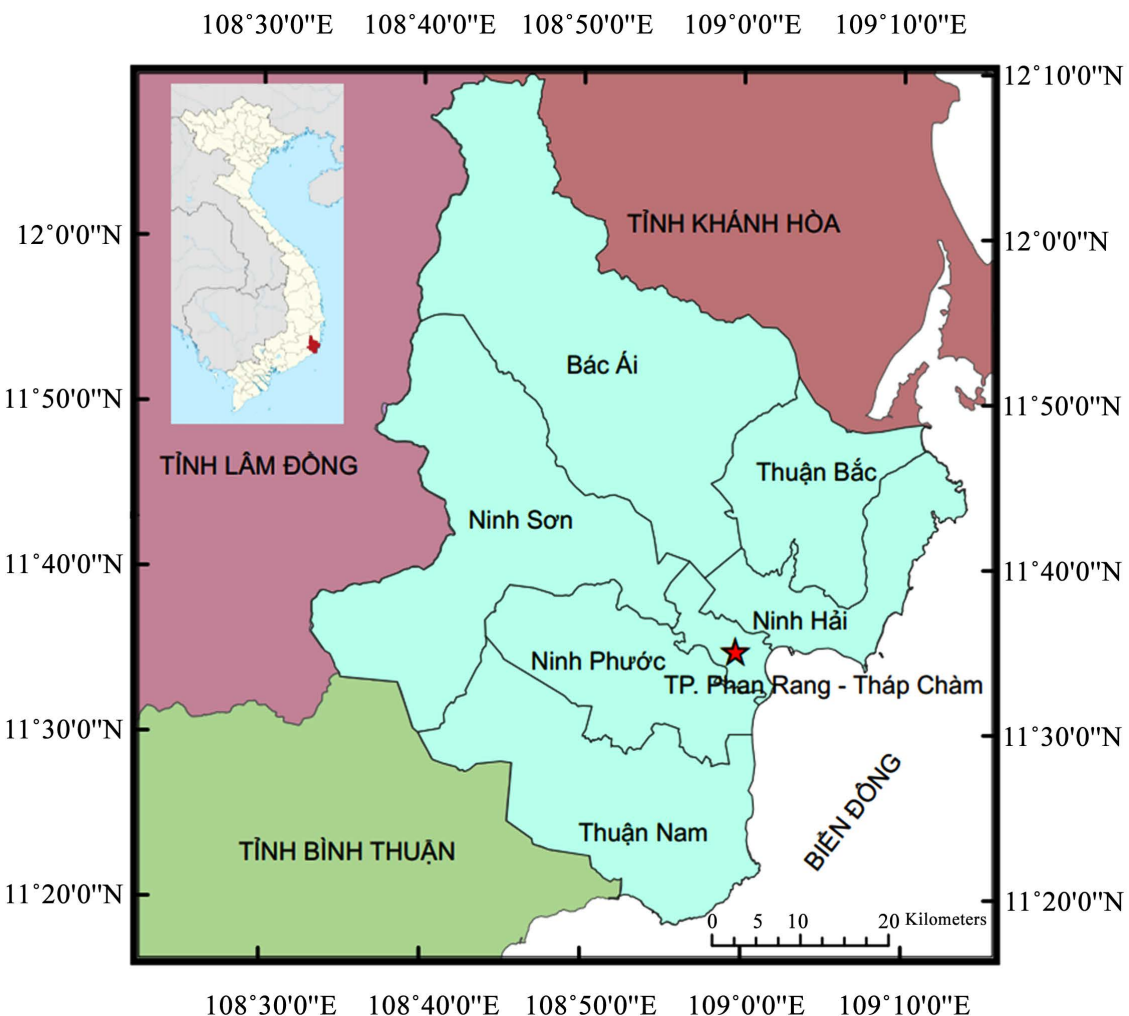

Figure 1. Study area. 


\section{Data and Methods}

\subsection{Data}

Research using the data of temperature and precipitation in the 1986-2016 period of the National Center for Meteorology and Hydrology, Scientific research about Hydrology of Ninh Thuan province done by the Southern Branch of the Institute of Meteorology, and the study on hydro-climatic characteristics of Ninh Thuan province by the Hydrometeorology Station of the South Central. The study data also use data from the Statistical yearbook of Ninh Thuan, Binh Thuan, Lam Dong, and Khanh Hoa provinces (Table 1).

\subsection{Methods}

According to research by Wilhite and Glantz and the American Meteorological Association, drought has been divided into four main categories: 1) meteorological drought; 2) hydrological drought; 3) agricultural drought; 4) socio-economic drought (AMS, 1997; Weltbank, 2006; Wilhite \& Glantz, 1985). Based on the research objectives of meteorological drought, agricultural drought and analysis of the trend of changes in the indicators of meteorological drought and agricultural drought, the research method of the topic is: 1) Method of calculating the index meteorological drought and agricultural drought; 2) Non-parametric methods include: Mann-Kendall and Theil-Sen.

\subsubsection{Standardized Precipitation Index (SPI)}

SPI was developed in 1993 by American scientists, including McKee, Doesken, and Kleist at Colorado State University, United States of America. This index is used to study drought caused by meteorology in the US (McKee et al., 1993;

Table 1. List of main stations used for research.

\begin{tabular}{|c|c|c|c|c|}
\hline \multirow{2}{*}{ Stations } & \multirow{2}{*}{ Local } & \multicolumn{2}{|c|}{ Geographic coordinate } & \multirow{2}{*}{ Data } \\
\hline & & Longitude & Latitude & \\
\hline Cam Ranh & Khanh Hoa & $109^{\circ} 09^{\prime} 00^{\prime \prime}$ & $11^{\circ} 55^{\prime} 00^{\prime \prime}$ & $\mathrm{T}^{0}$ \\
\hline Phan Thiet & Binh Thuan & $108^{\circ} 06^{\prime} 00^{\prime \prime}$ & $10^{\circ} 56^{\prime} 00^{\prime \prime}$ & $\mathrm{T}^{0}$ \\
\hline Da Lat & Lam Dong & $108^{\circ} 26^{\prime} 00^{\prime \prime}$ & $11^{\circ} 57^{\prime} 00^{\prime \prime}$ & $\mathrm{T}^{0}$ \\
\hline Ba Thap & Ninh Thuan & $109^{\circ} 03^{\prime} 00^{\prime \prime}$ & $11^{\circ} 42^{\prime} 00^{\prime \prime}$ & $\mathrm{P}$ \\
\hline $\mathrm{Ca} \mathrm{Na}$ & Ninh Thuan & $108^{\circ} 52^{\prime} 00^{\prime \prime}$ & $11^{\circ} 21^{\prime} 00^{\prime \prime}$ & $\mathrm{P}$ \\
\hline Nha Ho & Ninh Thuan & $108^{\circ} 54^{\prime} 00^{\prime \prime}$ & $11^{\circ} 42^{\prime} 00^{\prime \prime}$ & $\mathrm{P}$ \\
\hline Nhi Ha & Ninh Thuan & $108^{\circ} 40^{\prime} 00^{\prime \prime}$ & $11^{\circ} 28^{\prime} 00^{\prime \prime}$ & $\mathrm{P}$ \\
\hline Phan Rang & Ninh Thuan & $108^{\circ} 59^{\prime} 00^{\prime \prime}$ & $11^{\circ} 34^{\prime} 00^{\prime \prime}$ & $\mathrm{P}, \mathrm{T}^{0}$ \\
\hline Quan The & Ninh Thuan & $108^{\circ} 54^{\prime} 00^{\prime \prime}$ & $11^{\circ} 26^{\prime} 00^{\prime \prime}$ & $\mathrm{P}$ \\
\hline Song Pha & Ninh Thuận & $108^{\circ} 42^{\prime} 00^{\prime \prime}$ & $11^{\circ} 50^{\prime} 00^{\prime \prime}$ & $\mathrm{P}$ \\
\hline Tan My & Ninh Thuận & $108^{\circ} 49^{\prime} 29^{\prime \prime}$ & $11^{\circ} 42^{\prime} 00^{\prime \prime}$ & $\mathrm{P}$ \\
\hline
\end{tabular}

Note: T: temperature; P: precipitation. 
WMO, 2012). According to the World Meteorological Organization (WMO) and the Global Water Partnership (GWP), the SPI is recommended for use worldwide, with more than 70 countries already using it for drought research (WMO, 2012, 2014). Equation (1) calculates the SPI:

$$
\mathrm{SPI}=\frac{X-\bar{X}}{\delta}
$$

where: $X$ rainfall in time $i$ (month, season, season); $\bar{X}$ is average rainfall i over many years; $\delta$ is the standard deviation of precipitation over time $i$. The wet and dry weather conditions are the category of drought shown by the SPI index calculation (Table 2).

\subsubsection{Moisture Index (MI)}

The MI index is proposed in report no $1 / 48$ in $1978-81$ of FAO (FAO, 1978) and Vietnam. This method is also widely used in the study of agricultural drought (Doan Van Diem \& Tran Danh Thin, 2007; Le Thi Thu Hien, 2013; Pham Quang Vinh \& Pham Thi Thanh Huong, 2013).

Equation (2) calculates the MI:

$$
\mathrm{MI}=\mathrm{R} / \mathrm{PET}
$$

where: R: Average annual precipitation; PET: the annual average amount of evaporation capacity.

PET is calculated using the Thornthwaite method and has been used in many studies around the world (Adhikari et al., 2019; Hashemi \& Habibian, 1979; Moeletsi et al., 2013; Ogunrinde et al., 2020; Pereira \& Paes De Camargo, 1989; Pereira \& Pruitt, 2004; Thornthwaite, 1948; Zhou et al., 2020). DrinC 1.7 software (DrinC, 2019) was used to calculate PET. The results of the MI calculation are that the agricultural drought level is shown in Table 3. This software is the research result of the Centre for the Assessment of Natural Hazards and Proactive Planning \& Laboratory of Reclamation Works and Water Resources Management, National Technical University of Athens, Greece. DrinC software is considered a useful tool in international publications to analyze drought in arid and semi-arid regions (Tigkas et al., 2015, 2017, 2020).

Table 2. Drought classification based on SPI.

\begin{tabular}{cc}
\hline SPI & Category \\
SPI $>2.0$ & Extremely wet \\
1.5 SPI 1.99 & Severely wet \\
1.0 SPI 1.49 & Moderately wet \\
-0.99 SPI 0.99 & Near normal \\
-1.0 SPI -1.49 & Moderately drought \\
-1.5 SPI -1.99 & Severely drought \\
SPI $<-2$ & Extremely drought \\
\hline
\end{tabular}

Source: (McKee et al., 1993; WMO, 2012). 
Table 3. Drought classification based on MI.

\begin{tabular}{ccc}
\hline Level of moisture & MI & Level of drought \\
\hline Much moisture & $>1.2$ & Lessly drought \\
No shortage of moisture & $0.8-1.2$ & Significantly drought \\
Mild moisture deficiency & $0.4-0.79$ & Severely drought \\
Severe moisture deficiency & $<0.4$ & Extremely drought \\
\hline
\end{tabular}

Source: (Doan Van Diem \& Tran Danh Thin, 2007; Pham Quang Vinh \& Pham Thi Thanh Huong, 2013).

\subsubsection{Mann-Kendall Analysis and Theil-Sen Estimator}

Mann-Kendall (MK) method was developed by two scientists, Mann and Kendall (Kendall, 1975; Mann, 1945). The method used extensively in meteorological and hydrological studies around the world (Ahmed et al., 2014; Bayazit et al., 2019; Bera, 2017; Bhuyan et al., 2018; Cardoso et al., 2016; Chatterjee et al., 2015; Djaman et al., 2017; Ernest et al., 2017; Islam, 2015; Koudahe et al., 2017; Murumkar \& Arya, 2014; Nyatuame \& Agodzo, 2017; Okafor et al., 2017; Tian et al., 2012). Accordingly, the non-parametric method MK (S) is calculated by Equation (3):

$$
S=\sum_{i=1}^{N-1} \sum_{j=i+1}^{N} \operatorname{sgn}\left(x_{j}-x_{i}\right)
$$

and

$$
\operatorname{sgn}\left(x_{j}-x_{i}\right)= \begin{cases}+1 & \text { if }\left(x_{j}-x_{i}\right)>0 \\ 0 & \text { if }\left(x_{j}-x_{i}\right)=0 \\ -1 & \text { if }\left(x_{j}-x_{i}\right)<0\end{cases}
$$

As a result, $S>0$ is the uptrend and $S<0$ is the downturn. Also, to have a more accurate result and assessment, it is necessary to calculate the variance (VAR) (Helsel \& Hirsch, 1992). VAR is calculated by Equation (5):

$$
\operatorname{VAR}(S)=\frac{1}{18}\left[n(n-1)(2 n+5)-\sum_{p=1}^{g} t_{p}\left(t_{p}-1\right)\left(2 t_{p}+5\right)\right]
$$

where $t_{p}$ is considered the number of relationships with the sample $p, g$ is the number of groups with the same data values. If the value of $\operatorname{VAR}(S)>0$, then the trend is positive, and the $\operatorname{VAR}(S)<0$, then the trend is negative (Azad et al., 2014), the Equation (6) calculates the MK (Z) index:

$$
\begin{aligned}
& Z=\frac{S-1}{[\operatorname{VAR}(S)]^{1 / 2}}, S>0 \\
& Z=0, S=0 \\
& Z=\frac{S+1}{[\operatorname{VAR}(S)]^{1 / 2}}, S<0
\end{aligned}
$$

If $Z>0$, the trend is up; $Z<0$, downtrend.

Analysis Sen's slop was developed in 1950 by Theil and developed by Sen in 1968 (Sen, 1968; Theil, 1950). Equation (7) calculates the estimated slope of Sen: 


$$
Q=\frac{x_{i}^{\prime}-x_{i}}{i^{\prime}-i} \text { for } i=1,2,3, \cdots, n
$$

where, $Q$. The slope between data two points $x_{i}$ and $x_{i}^{\prime} ; x_{i}^{\prime}$ data measurement at the time $i^{\prime} ; x_{i}$ data measurement at time $i ; i^{\prime}$ time after time $i$

Sen's slope estimate is the mean slope $(Q)$, calculated using the Equation (8):

$$
Q^{\prime}= \begin{cases}Q\left\lceil\frac{N+1}{2}\right\rceil & \text { if } N \text { old } \\ \frac{Q[N+1]+Q[N+2]}{2} & \text { if } N \text { even }\end{cases}
$$

$N$ is the number of calculator slope.

A two-sided test calculates $Q$ with a confidence of $100(1-\alpha) \%$, and then an actual slope can be obtained by the non-parametric test. If $Q>0.0$, then increase and $Q<0.0$ value tends to decrease (Azad et al., 2014).

The software selected for the Mann-Kendall and Theil-Sen calculations is ProUCL 5.1 and Makesens 1.0. ProUCL is a comprehensive statistical software with statistical methods and graphical tools to solve many environmental sampling and statistics problems, software developed by the US Environmental Protection Agency (EPA, 2016). Makesens 1.0 was developed on the Excel platform of the Finnish Meteorological Institute. This program is used to study trends in atmospheric concentration change, precipitation and has been widely applied in coin research meteorological change (Salmi et al., 2002).

\section{Result and Discussion}

\subsection{Result of Drought}

\subsubsection{Standardized Precipitation Index Result}

The calculation results of SPI 1, SPI 3, SPI 6, and SPI 12 showed that drought occurred in the study period with different types of drought. Synthesized results of the months of 1986-2016 show that the whole Ninh Thuan province appeared 16 times (months) with Extreme drought, 85 times of severe drought, 199 times of moderate drought, and 1157 times of near normal. The whole province had 215 times of moderately wet, severely wet, 121 times, and extremely wet 22 times (Table 4, Figure 2).

Table 4. SPI calculation result and drought levels.

\begin{tabular}{cccccccc}
\hline & \multicolumn{7}{c}{ Drought levels } \\
\cline { 2 - 8 } SPI & $\begin{array}{c}\text { Extremely } \\
\text { wet }\end{array}$ & $\begin{array}{c}\text { Severely } \\
\text { wet }\end{array}$ & $\begin{array}{c}\text { Moderately } \\
\text { wet }\end{array}$ & $\begin{array}{c}\text { Near } \\
\text { normal }\end{array}$ & $\begin{array}{c}\text { Moderately } \\
\text { drought }\end{array}$ & $\begin{array}{c}\text { Severely } \\
\text { drought }\end{array}$ & $\begin{array}{c}\text { Extremely } \\
\text { drought }\end{array}$ \\
\hline SPI 1 & 8 & 21 & 33 & 258 & 31 & 14 & 4 \\
SPI 3 & 7 & 22 & 40 & 232 & 45 & 15 & 6 \\
SPI 6 & 1 & 32 & 38 & 234 & 30 & 23 & 4 \\
SPI 12 & 3 & 22 & 55 & 210 & 52 & 15 & 1 \\
Total & 22 & 121 & 215 & 1157 & 199 & 85 & 16 \\
\hline
\end{tabular}




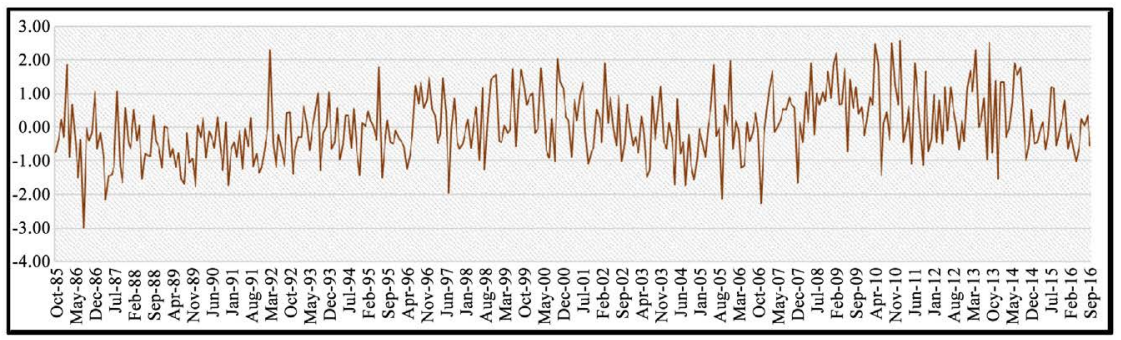

(a)

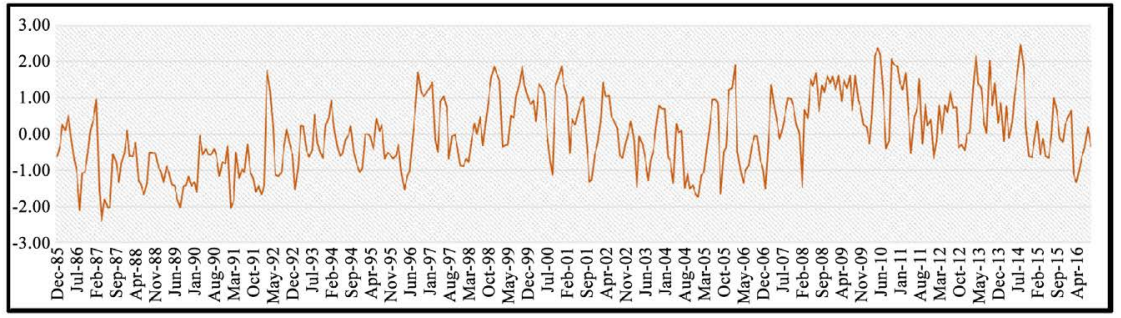

(b)

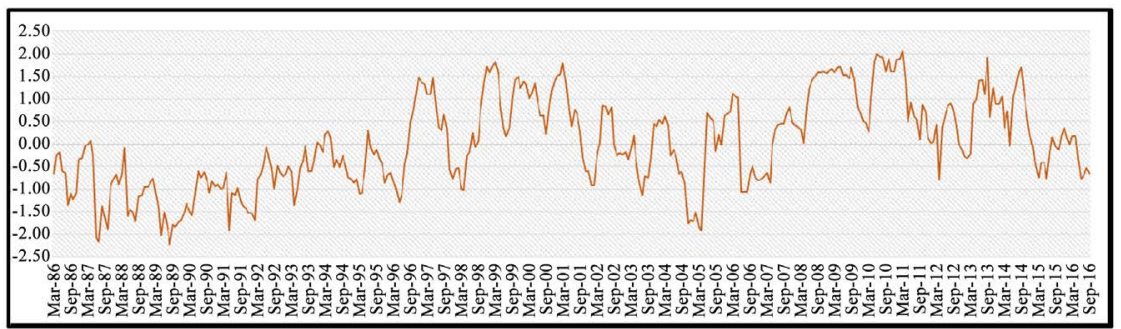

(c)

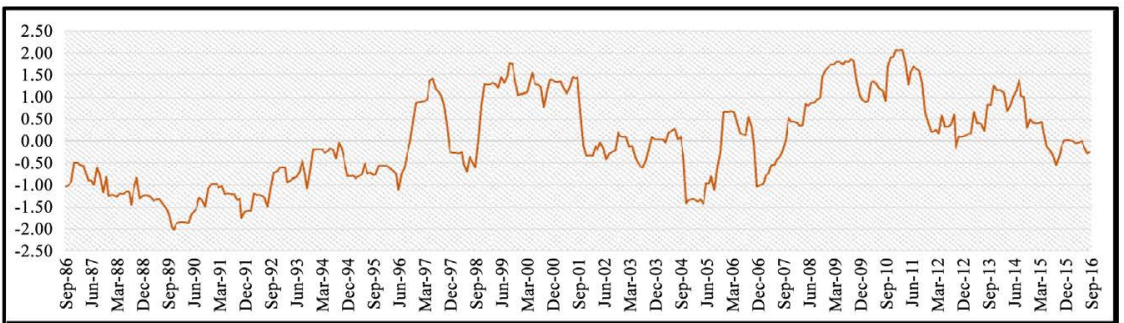

(d)

Figure 2. Drought characteristics according to the SPI 1, SPI 3, SPI 6, SPI 12. (a) SPI 1-month; (b) SPI 3-month; (c) SPI 6-month; (d) SPI 12-month.

On the other hand, the calculation results of SPI 1, SPI 3, SPI 6, and SPI 12 showed that drought occurred in the study period with different forms. SPI 1 month, the number of droughts occurred the most with 258 times, while the number of droughts (moderately drought, severely drought, and extremely drought) was 49 times, the number of times was wet (extremely wet, severely wet, and moderately wet) was 62 times. (Table 4, Figure 2(a)). SPI 3 month, the number of droughts occurring less than the number of droughts occurred 66 times with droughts and 69 times with humidity (Table 4, Figure 2(b)). SPI 6 month, the number of wet occurrences is 71 times higher than that of drought is 59 times (Table 3, Figure 2(c)). Finally, in SPI 12 month, the drought is 68 times while the humidity occurs 80 times (Table 4, Figure 2(d)). 


\subsubsection{Moisture Index Result}

Analyzing the results of calculating the MI index to assess agricultural drought in Ninh Thuan province, the results showed that agricultural drought is happening at different levels of drought, but mainly severe and significant drought (Figure 3). Analysis of Figure 3 and Table 5 shows that in 1986-2016, the whole Ninh Thuan province suffered from severe drought with an average of MI 0.66 $(0.4<\mathrm{MI}<0.79)$. Significant drought appeared 7 times with a frequency of $23 \%$; severe drought occurred 23 times with a frequency of $74 \%$ and only one extreme drought in 1988 with a frequency of $3 \%$. However, it is necessary to pay attention to the time when severe droughts appeared in 1986-2016. Severely droughts appeared continuously in many years, such as 1986 to 1995 (except 1988 because of extreme droughts), 2001 to 2006, and 2011 to 2015.

The MI index by month shows that MI is the lowest from December to April with MI below 0.4, which corresponds to extreme drought since this is a time of very little rainfall and sometimes no rain; from May to August, Ninh Thuan province experienced severe drought, September has drought significantly; Lessly drought in October and November with the MI index of 1.43 and 1.30, respectively (Figure 4).

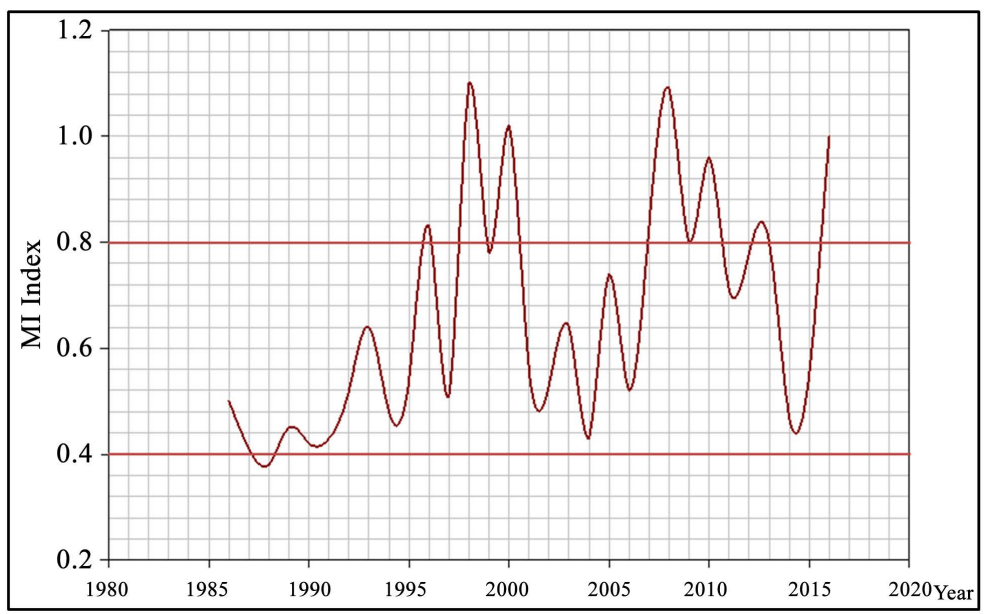

Figure 3. Drought events in Ninh Thuan from 1986 to 2016 according to the MI index.

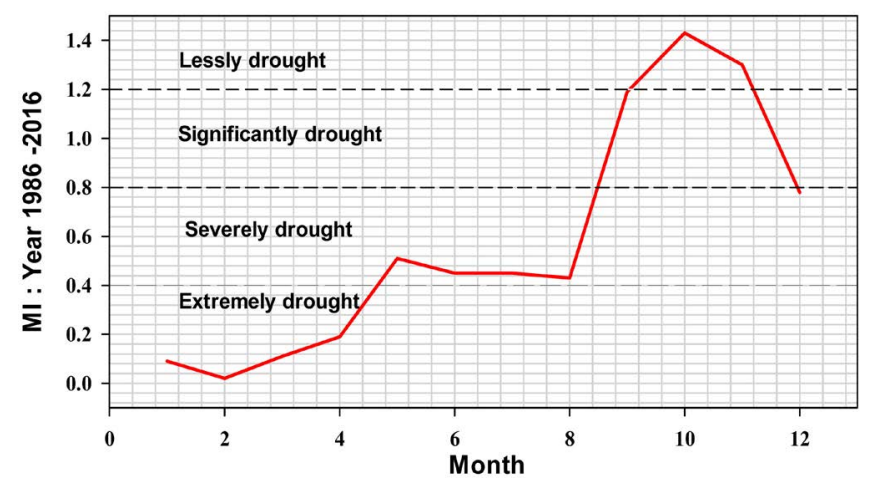

Figure 4. Agricultural drought event appeared in the period 1986-2016 by month in Ninh Thuan. 
Table 5. The result of Agricultural drought classification according to MI index.

\begin{tabular}{|c|c|c|c|c|c|}
\hline \multirow[b]{2}{*}{ Year } & \multicolumn{5}{|c|}{ Drought levels } \\
\hline & MI & $\begin{array}{l}\text { Lessly } \\
\text { drought }\end{array}$ & $\begin{array}{l}\text { Significantly } \\
\text { drought }\end{array}$ & $\begin{array}{l}\text { Severely } \\
\text { drought }\end{array}$ & $\begin{array}{c}\text { Extremely } \\
\text { drought }\end{array}$ \\
\hline 1986 & 0.50 & 0 & 0 & 1 & 0 \\
\hline 1987 & 0.41 & 0 & 0 & 1 & 0 \\
\hline 1988 & 0.38 & 0 & 0 & 0 & 1 \\
\hline 1989 & 0.45 & 0 & 0 & 1 & 0 \\
\hline 1990 & 0.42 & 0 & 0 & 1 & 0 \\
\hline 1991 & 0.43 & 0 & 0 & 1 & 0 \\
\hline 1992 & 0.52 & 0 & 0 & 1 & 0 \\
\hline 1993 & 0.64 & 0 & 0 & 1 & 0 \\
\hline 1994 & 0.48 & 0 & 0 & 1 & 0 \\
\hline 1995 & 0.54 & 0 & 0 & 1 & 0 \\
\hline 1996 & 0.83 & 0 & 1 & 0 & 0 \\
\hline 1997 & 0.51 & 0 & 0 & 1 & 0 \\
\hline 1998 & 1.10 & 0 & 1 & 0 & 0 \\
\hline 1999 & 0.78 & 0 & 0 & 1 & 0 \\
\hline 2000 & 1.02 & 0 & 1 & 0 & 0 \\
\hline 2001 & 0.56 & 0 & 0 & 1 & 0 \\
\hline 2002 & 0.53 & 0 & 0 & 1 & 0 \\
\hline 2003 & 0.64 & 0 & 0 & 1 & 0 \\
\hline 2004 & 0.43 & 0 & 0 & 1 & 0 \\
\hline 2005 & 0.74 & 0 & 0 & 1 & 0 \\
\hline 2006 & 0.52 & 0 & 0 & 1 & 0 \\
\hline 2007 & 0.83 & 0 & 1 & 0 & 0 \\
\hline 2008 & 1.09 & 0 & 1 & 0 & 0 \\
\hline 2009 & 0.80 & 0 & 0 & 1 & 0 \\
\hline 2010 & 0.96 & 0 & 1 & 0 & 0 \\
\hline 2011 & 0.71 & 0 & 0 & 1 & 0 \\
\hline 2012 & 0.78 & 0 & 0 & 1 & 0 \\
\hline 2013 & 0.80 & 0 & 0 & 1 & 0 \\
\hline 2014 & 0.47 & 0 & 0 & 1 & 0 \\
\hline 2015 & 0.55 & 0 & 0 & 1 & 0 \\
\hline 2016 & 1.00 & 0 & 1 & 0 & 0 \\
\hline & & 0 & 7 & 23 & 1 \\
\hline & & 0 & 23 & 74 & 3 \\
\hline
\end{tabular}




\subsection{Evaluate the Trend of Change of SPI and MI}

\subsubsection{The Trend of Meteorological Drought}

Based on the results of MK (Table 5), that the (Z) value is always positive from SPI 1, SPI 3, SPI 6, and SPI 12, which shows that the meteorological term index is tending to increase with the indices specific and corresponding to Theil-Sen slope.

Considering the SPI 1 index, it has a different increase or decreases during the research period, with the standard value $(Z)$ equal to 6.056 and the slope of Thiel-Sen equal to 0.0028 ; this proves that the term index is trending increasing with an increase corresponding to the Theil-Sen index and that the drought tends to decrease (Table 6, Figure 5(a)). SPI 3 months study shows a positive standard value of 8.451 , the standard deviation is 2377 , and the slope of Theil-Sen is 0.000138 . It shows that the 3-month SPI has an increase of 0.000138 in the meteorological term, which means that the term tends to decrease, but with the Theil-Sen index is too small, the meaning is not high (Table 6, Figure 5 (b)). The SPI 6 month index also tended to increase with the Thiel-Sen slope of 0.000174 along with the standard value $Z>0$ with SPI 6 of 10.69 (Table 6, Figure 5(c)). SPI 12 months, a positive $Z$ value means an uptrend with the $Z$ index equal to 12.21 and the slope Theil-Sen equal to 0.00582; the results show that drought in Ninh Thuan has a downward trend due to the number of SPI increased (Table 6, Figure 5(d)).

There is a clear differentiation of each region's characteristics in terms of the SPI index level for Ninh Thuan stations. The trend calculation results of indexes SPI 1, SPI 3, SPI 6, and SPI 12 (Figure 6).

At Tan My station, the SPI has a trend increasing, but the slow increase means that the drought tends to decrease, but not much because the coefficient of standard $\mathrm{Z}$ is low, ranging from 0.9 to 4.8 , with the Thiel-Sen coefficient in the range from 0.001 to 0.016 .

The Song Pha station shows that the area tends to increase and increase more than the Tan My area. The analytical results showed that the standard $Z$ value is relatively high with a range of 2.5 to 9.2 , and the Thiel-Sen increases in the range 0.002 to 0.080 .

At Quan The station, trend test results show an uptrend in most of the indexes. The test results from Table 7 show that Z's expected value is positive for the indices, and the slope Theil-Sen is also always positive. Theil-Sen coefficient as

Table 6. Analysis of trends in the change of meteorological drought index by SPI index (1, 3,6 , and 12) in Ninh Thuan.

\begin{tabular}{ccccc}
\hline Result (MK and Sen's slope) & SPI 1 & SPI 3 & SPI 6 & SPI 12 \\
\hline Var (S) & 2396 & 2377 & 2348 & 2291 \\
Z (MK) & 6.056 & 8.451 & 10.690 & 12.210 \\
p-value & $6.994 \mathrm{E}-10$ & 0.000 & 0.000 & 0.000 \\
Sen's slope & $\mathbf{0 . 0 0 2 8}$ & $\mathbf{0 . 0 0 0 1 3 8}$ & $\mathbf{1 . 7 4 E}-\mathbf{0 4}$ & $\mathbf{0 . 0 0 5 8 2}$ \\
\hline
\end{tabular}




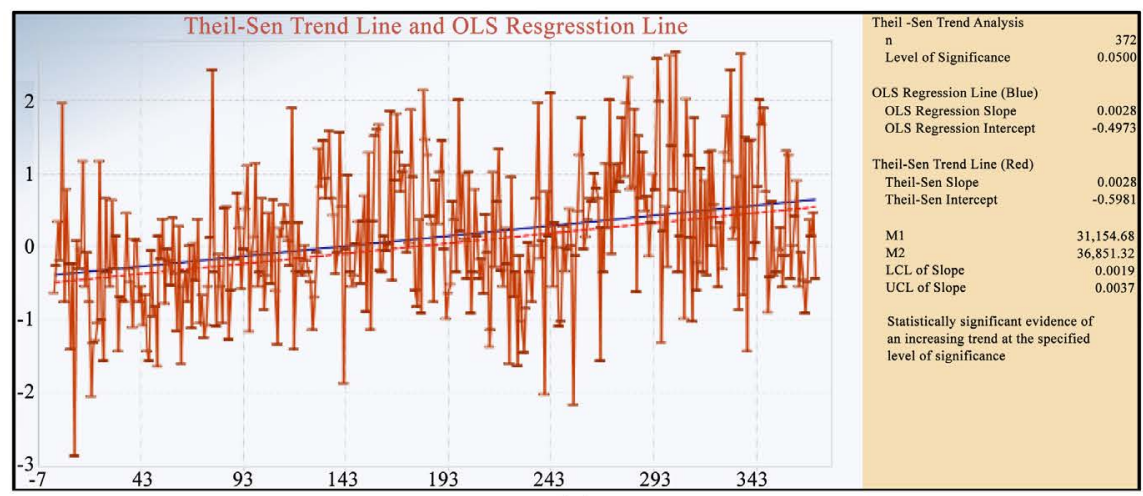

(a)

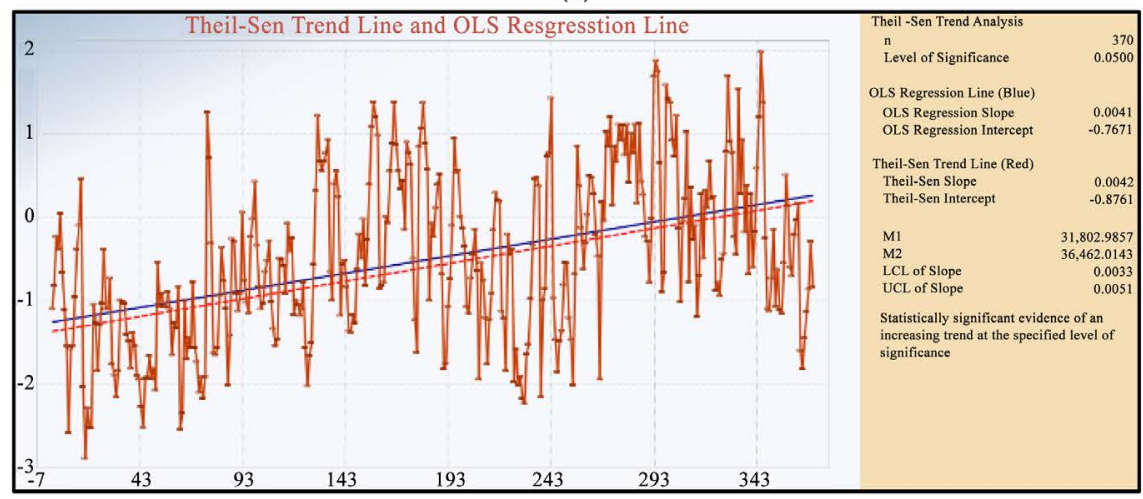

(b)

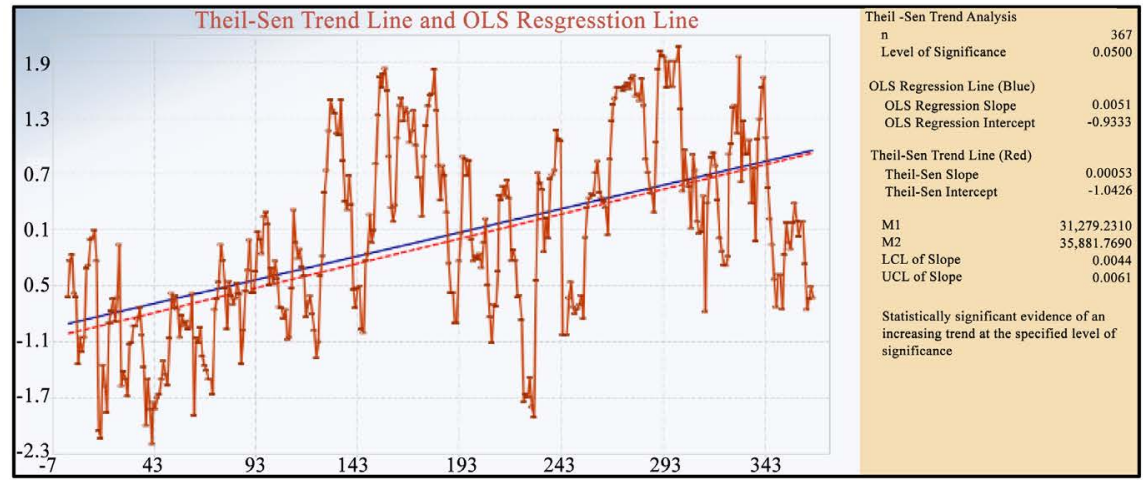

(c)

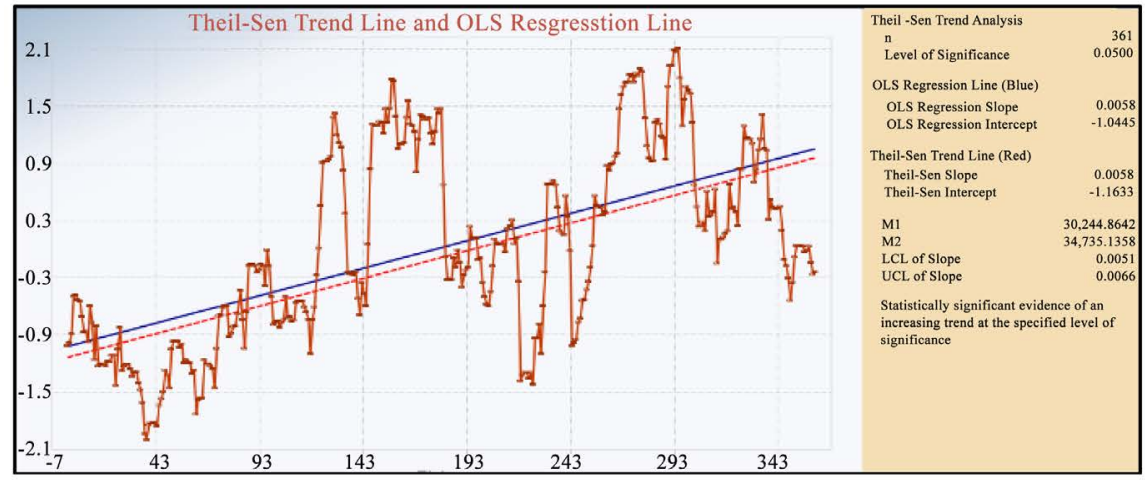

(d)

Figure 5. Results of SPI 1, 3, 6, and 12 analysis by Mann-Kendall. (a) MK-SPI 1 month; (b) MK-SPI 3 month; (c) MK-SPI 6 month; (d) MK-SPI 12 month. 


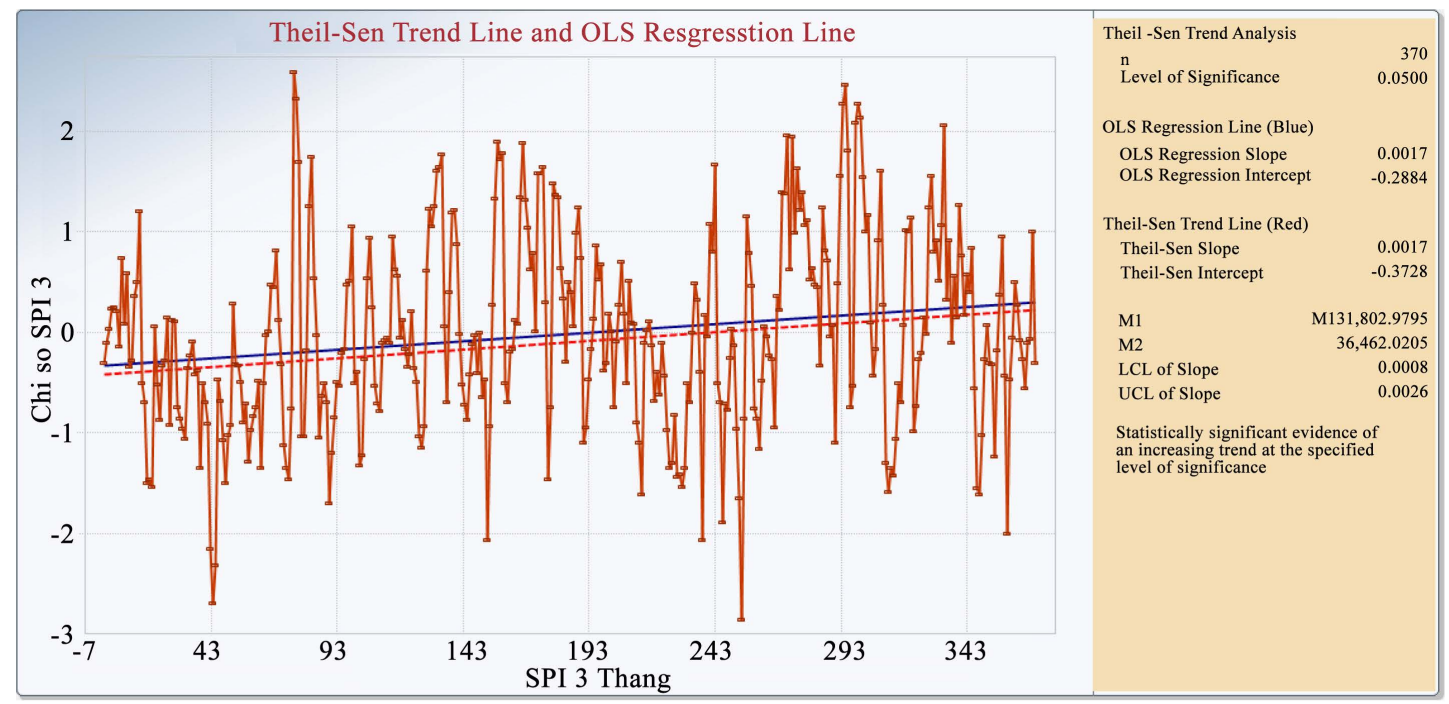

SPI 1 - station - Tan My

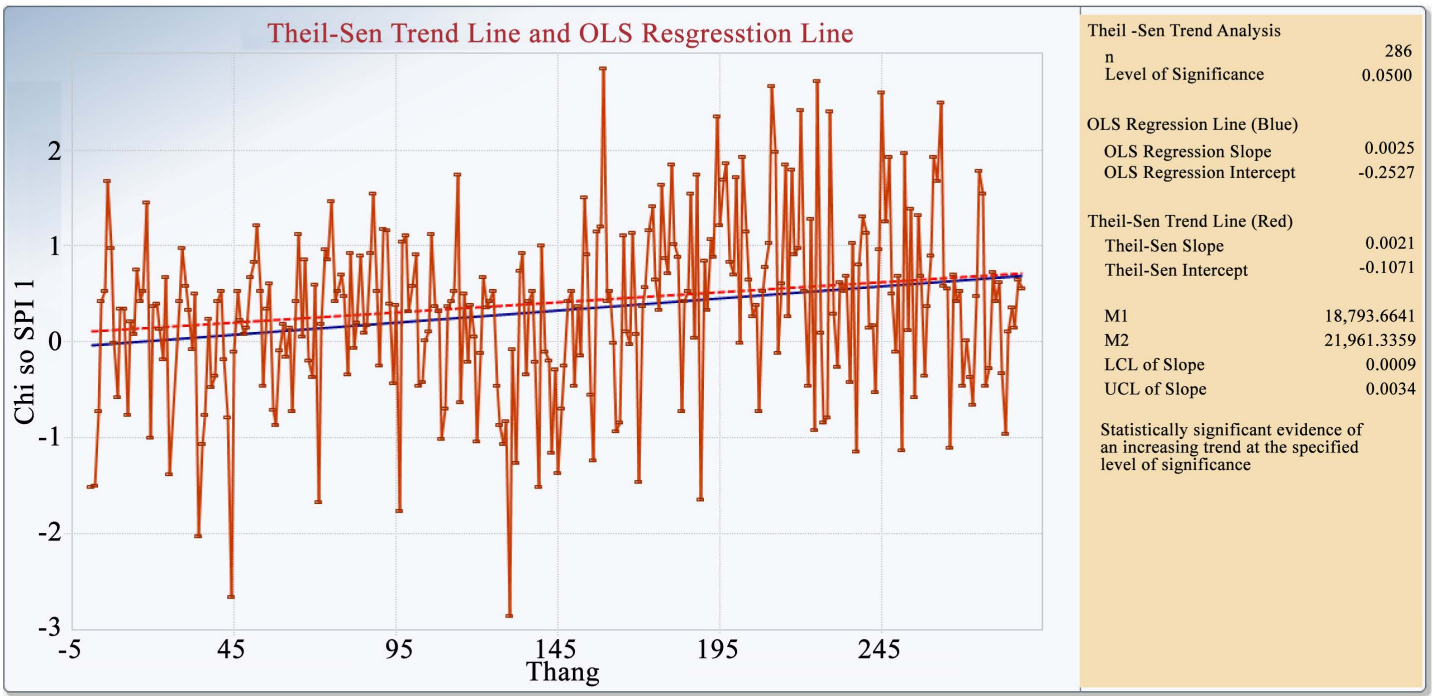

SPI 1 - station - Song Pha

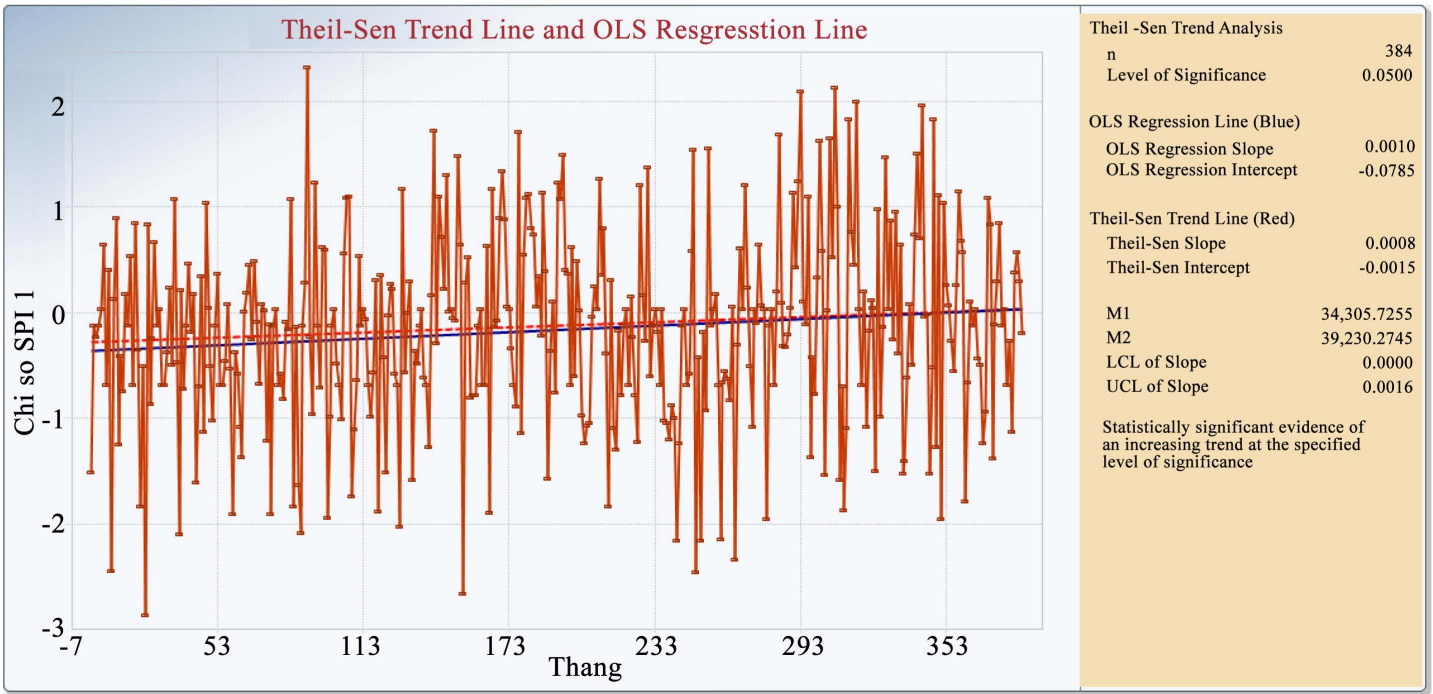

SPI 1 - station - Quan The 


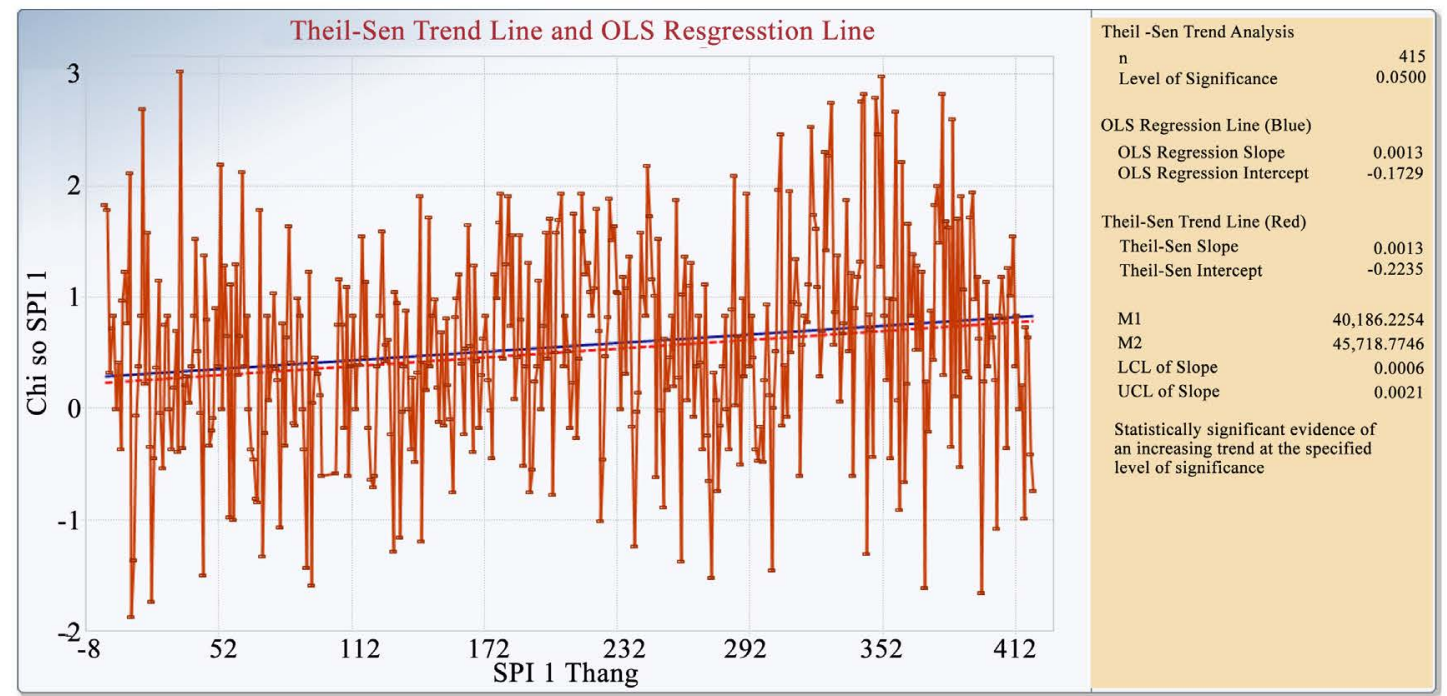

SPI 1 - station - Phan Rang

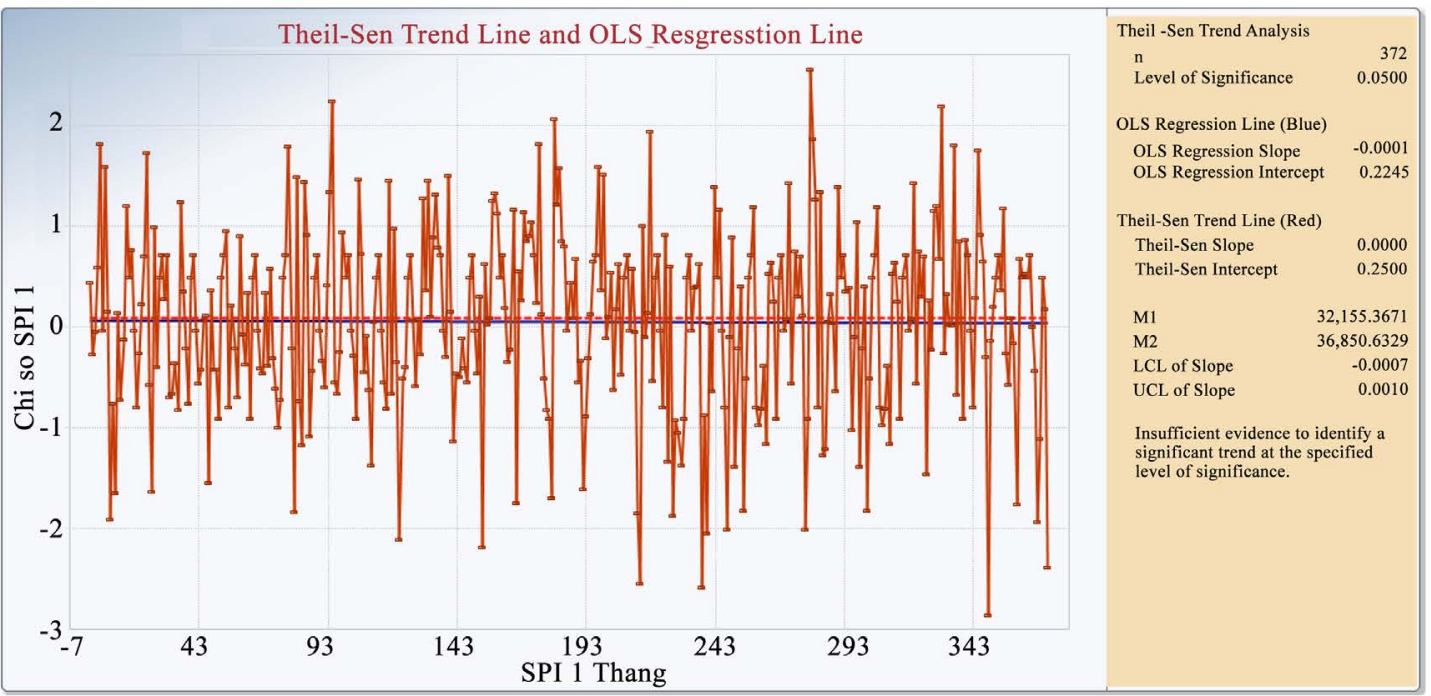

SPI 1 - station - Nhi Ha

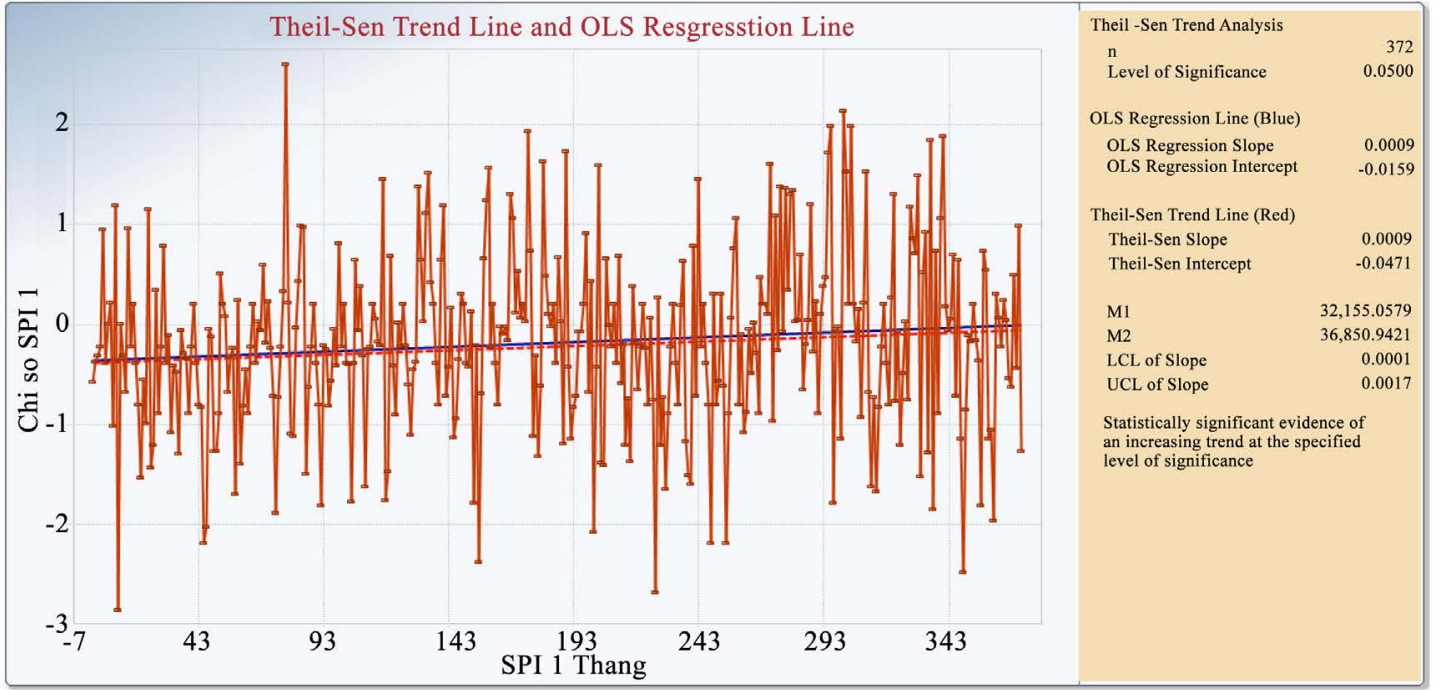

SPI 1 - station - Ba Thap 


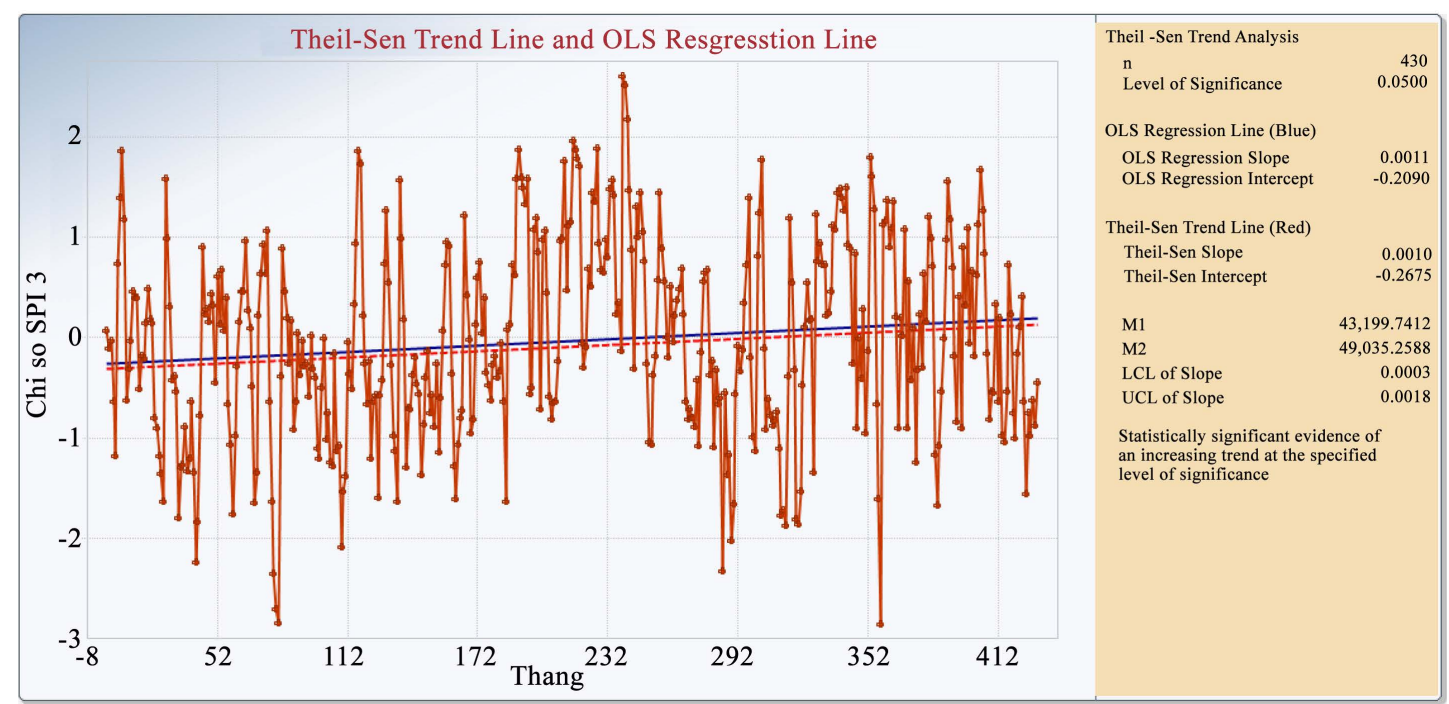

SPI 3 month - station - Tan My

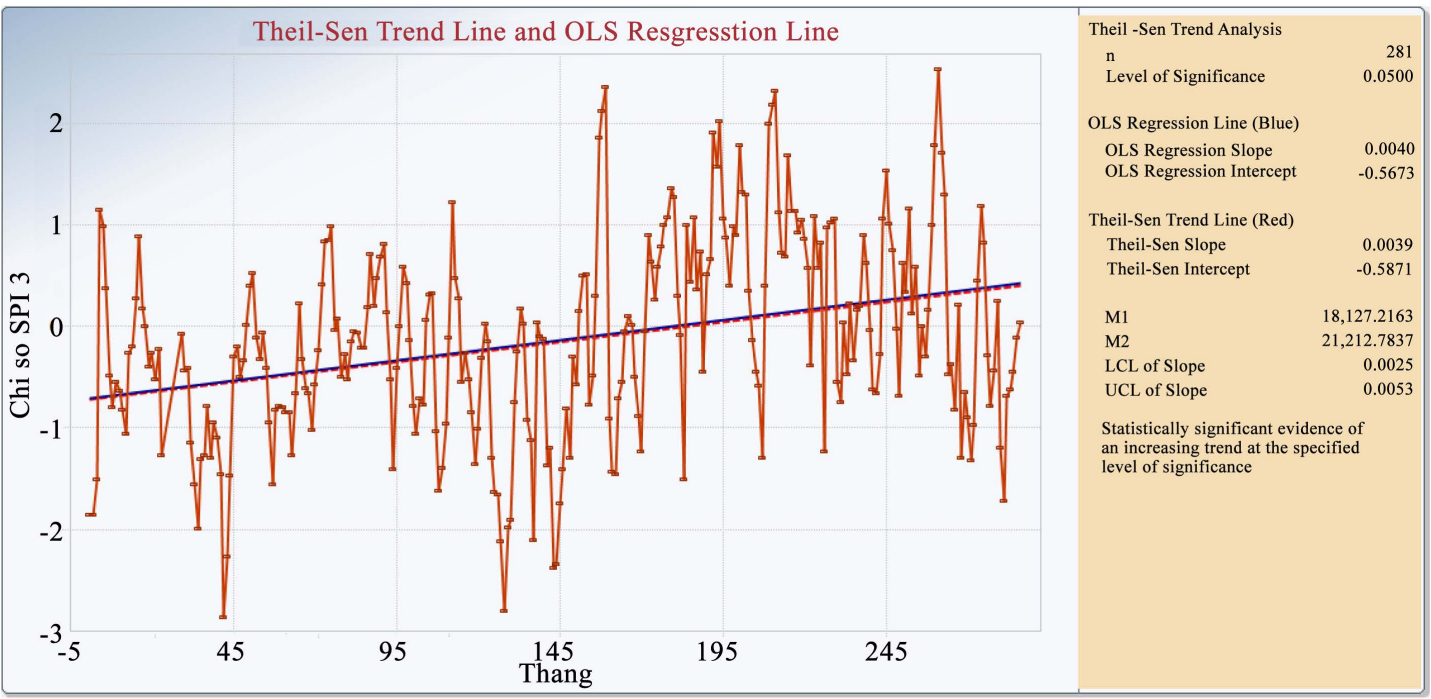

SPI 3 month - station - Song Pha

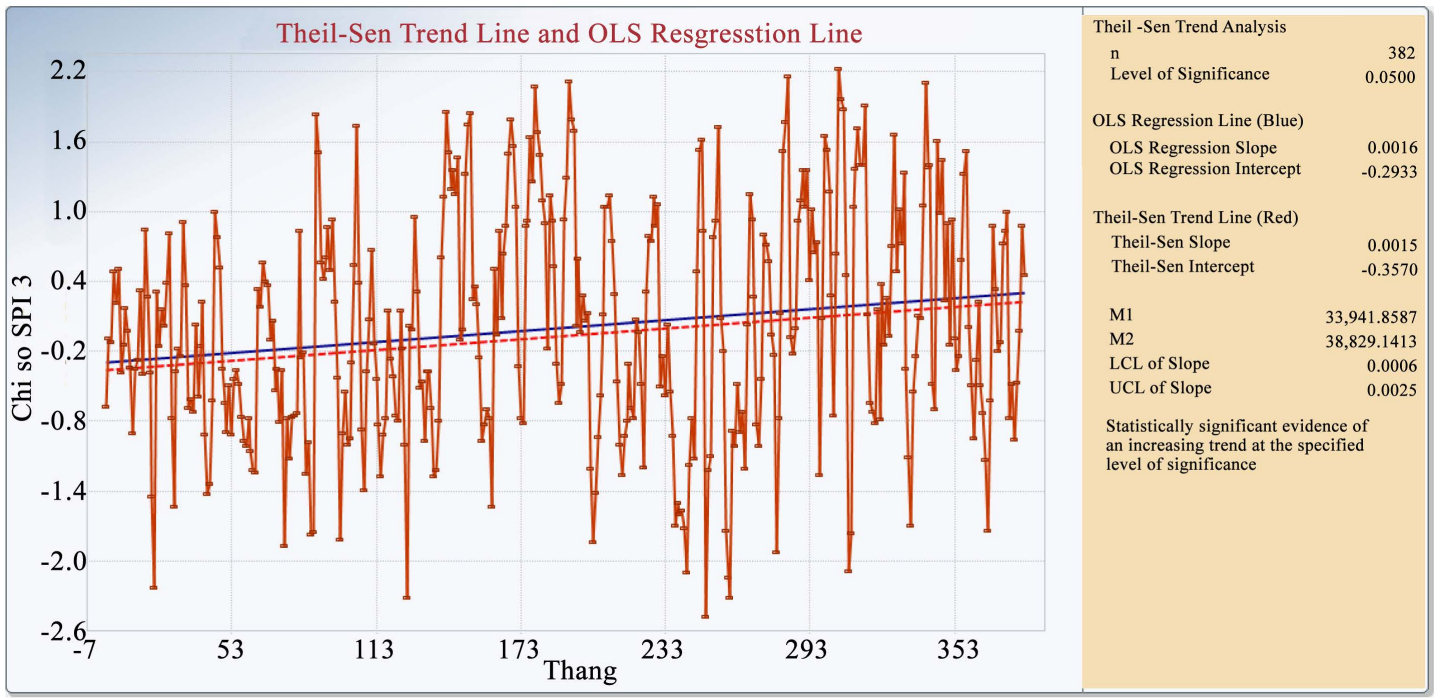

SPI 3 month - station - Quan The 


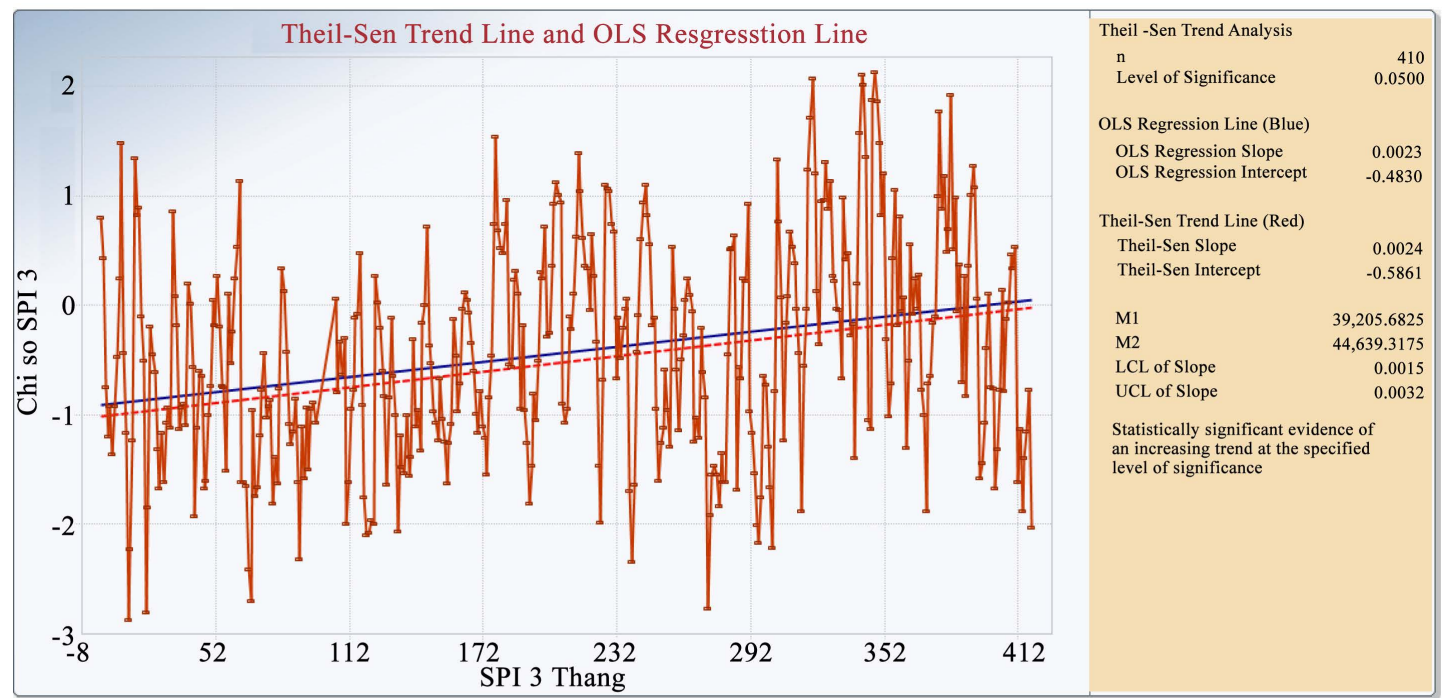

SPI 3 month - station - Phan Rang

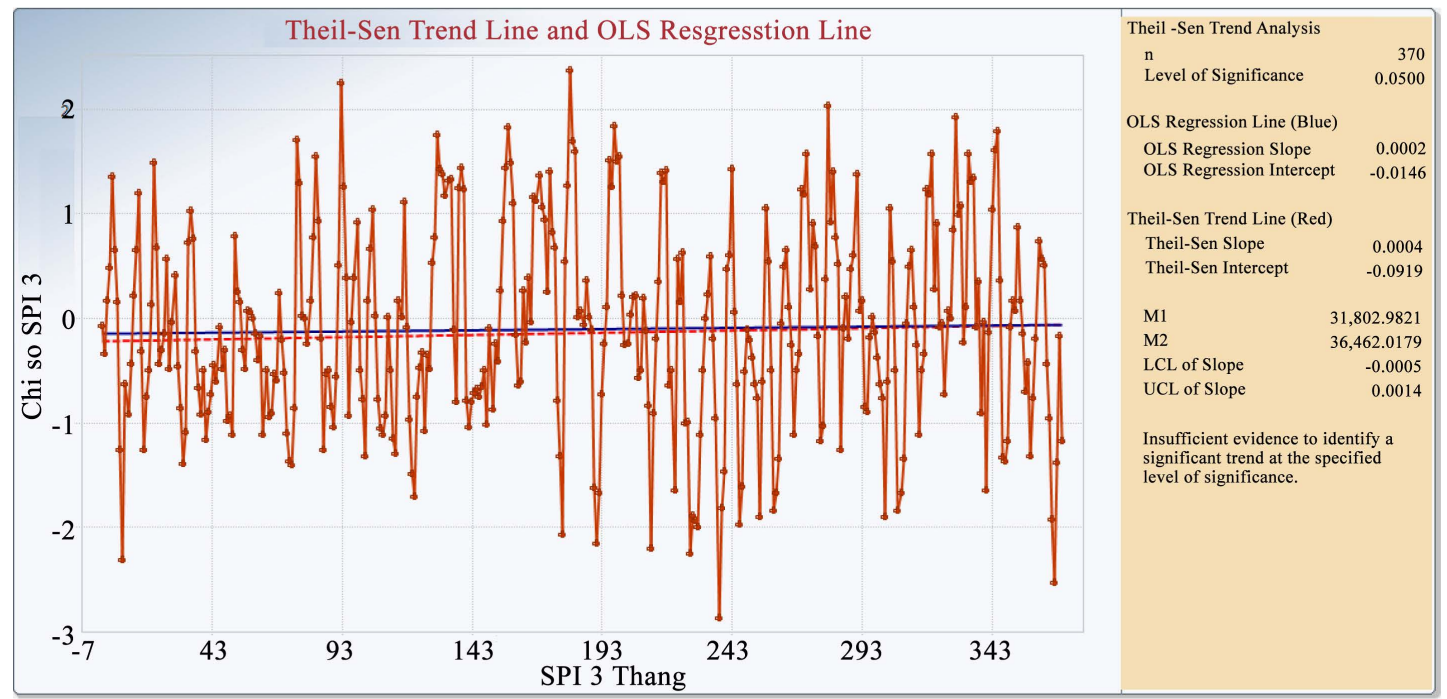

SPI 3 month - station - Nhi Ha

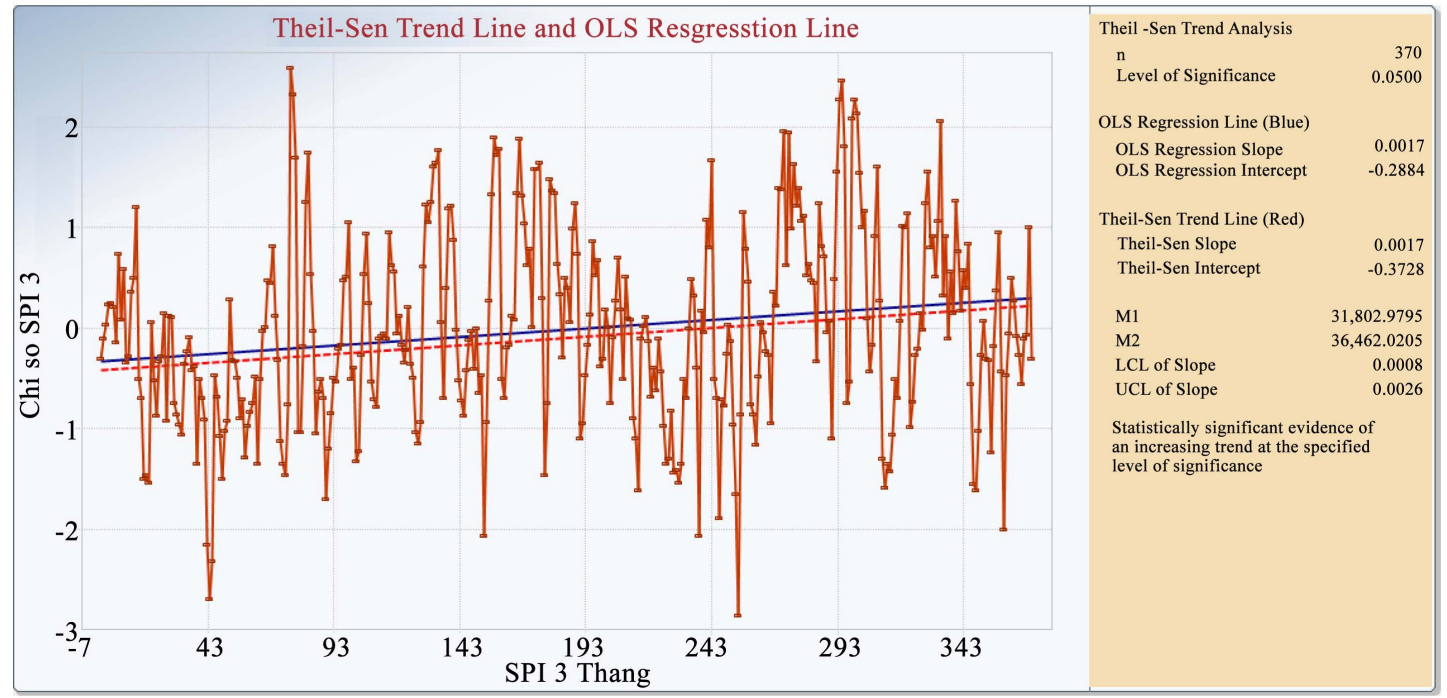

SPI 3 month - station - Ba Thap 


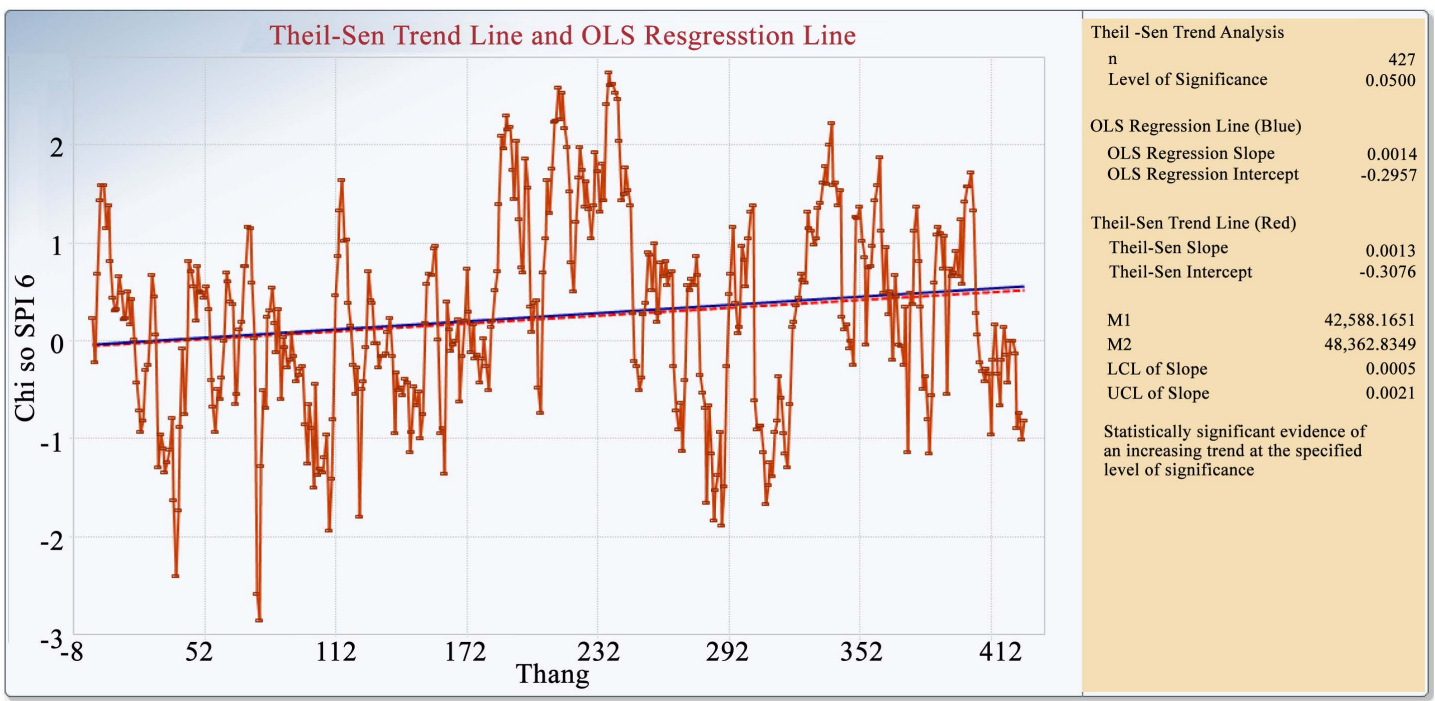

SPI 6 month - station - Tan My

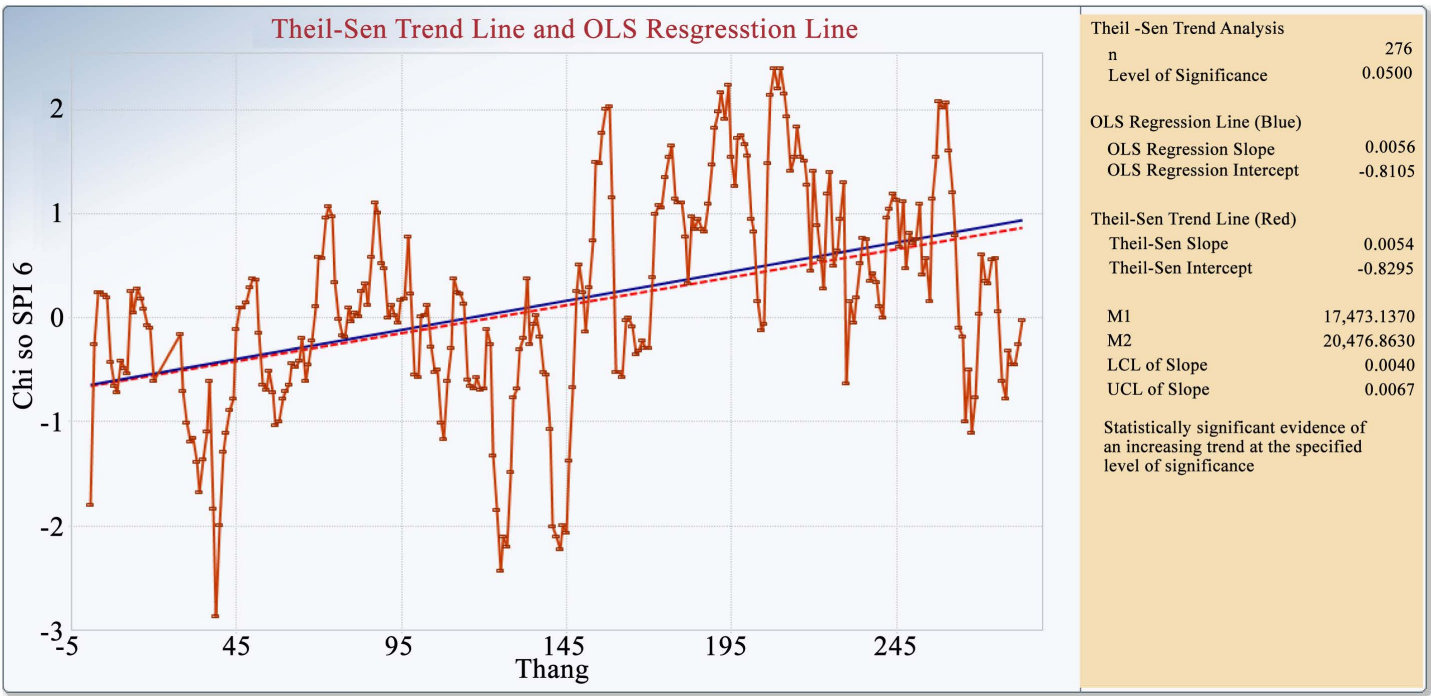

SPI 6 month - station - Song Pha

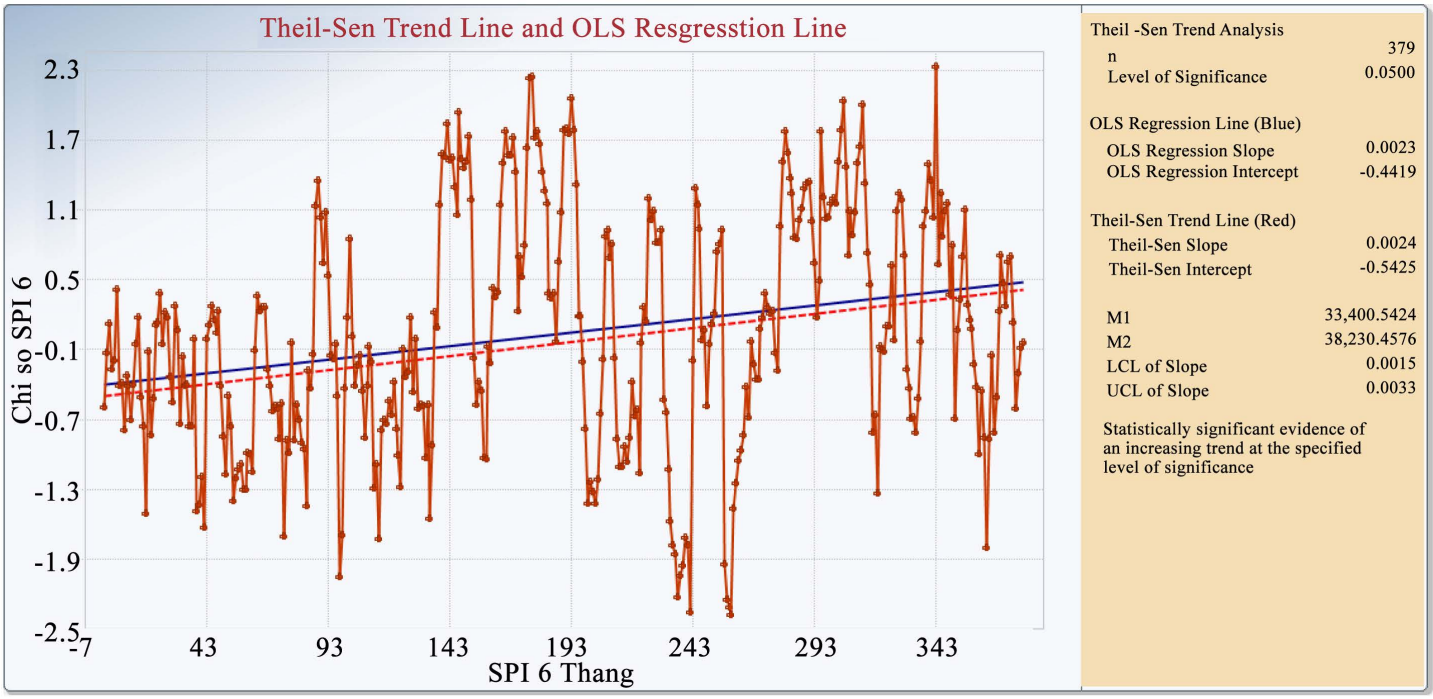

SPI 6 month - station - Quan The 


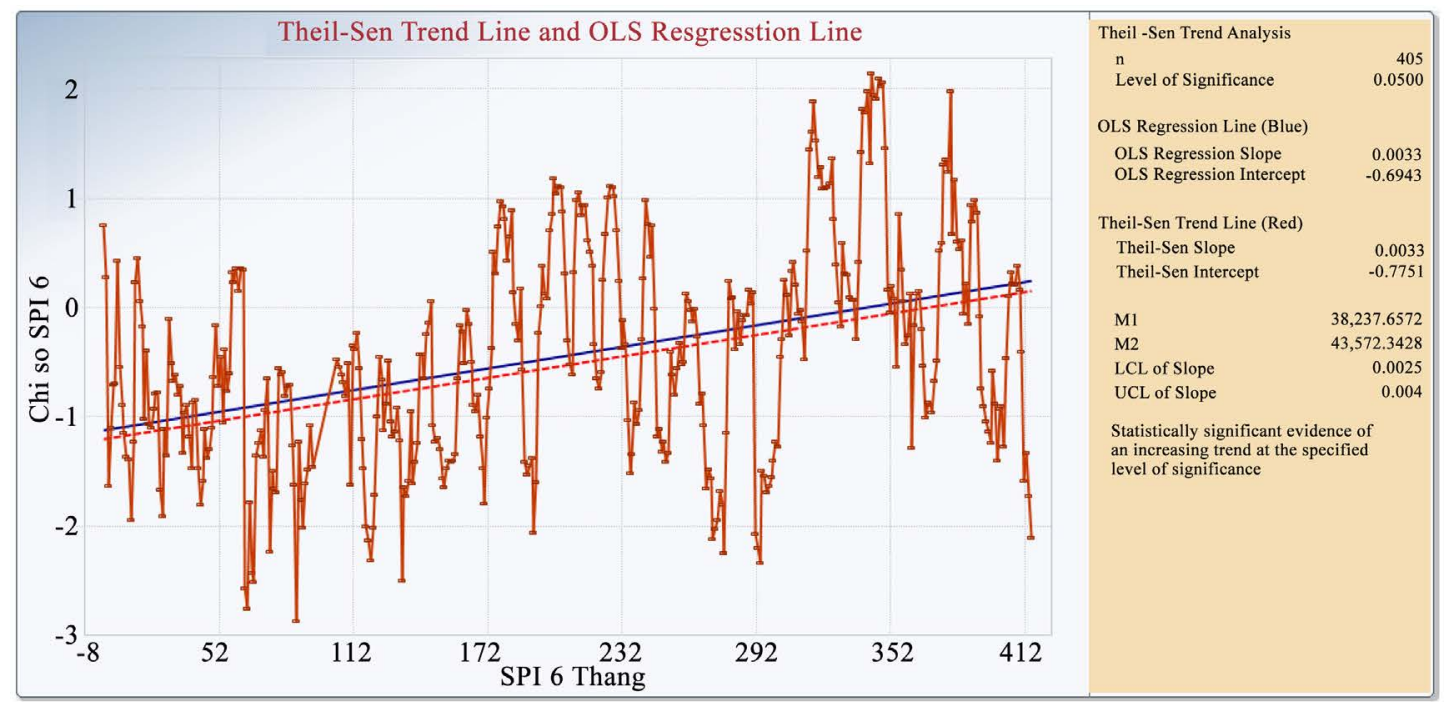

SPI 6 month - station - Phan Rang

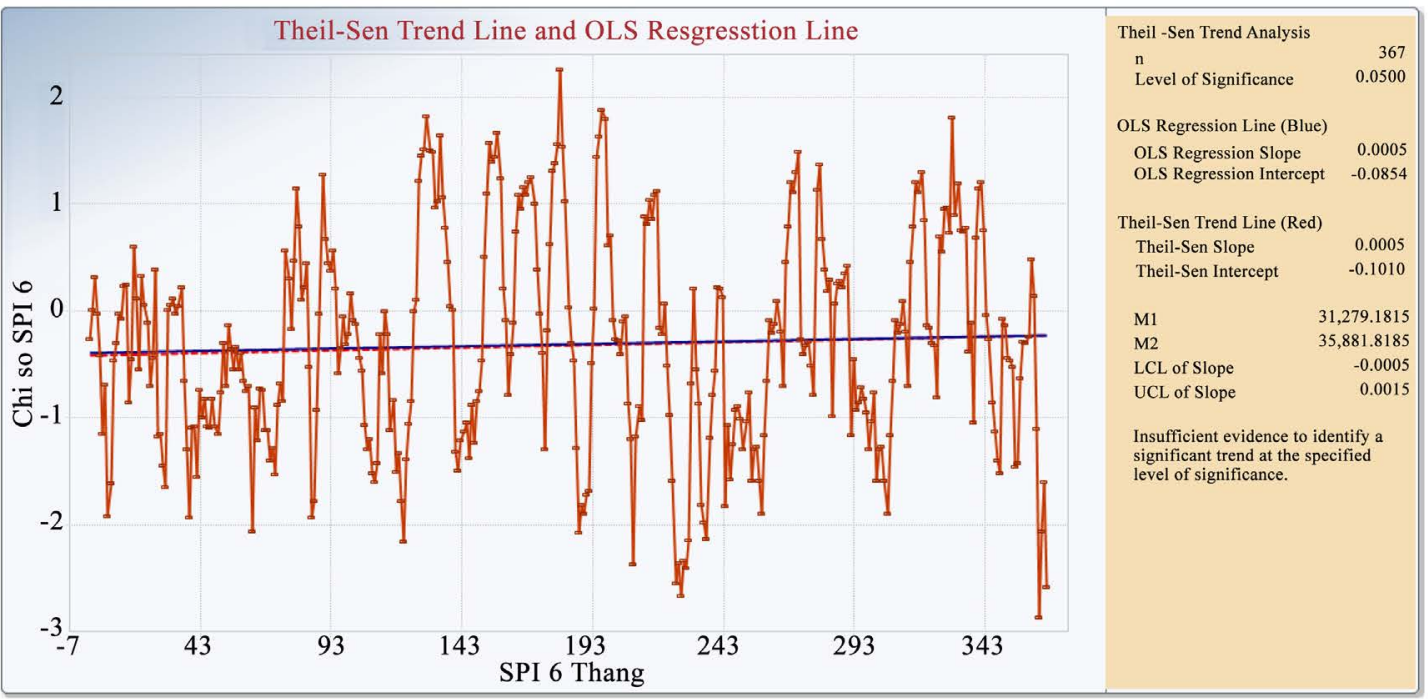

SPI 6 month - station - Nhi Ha

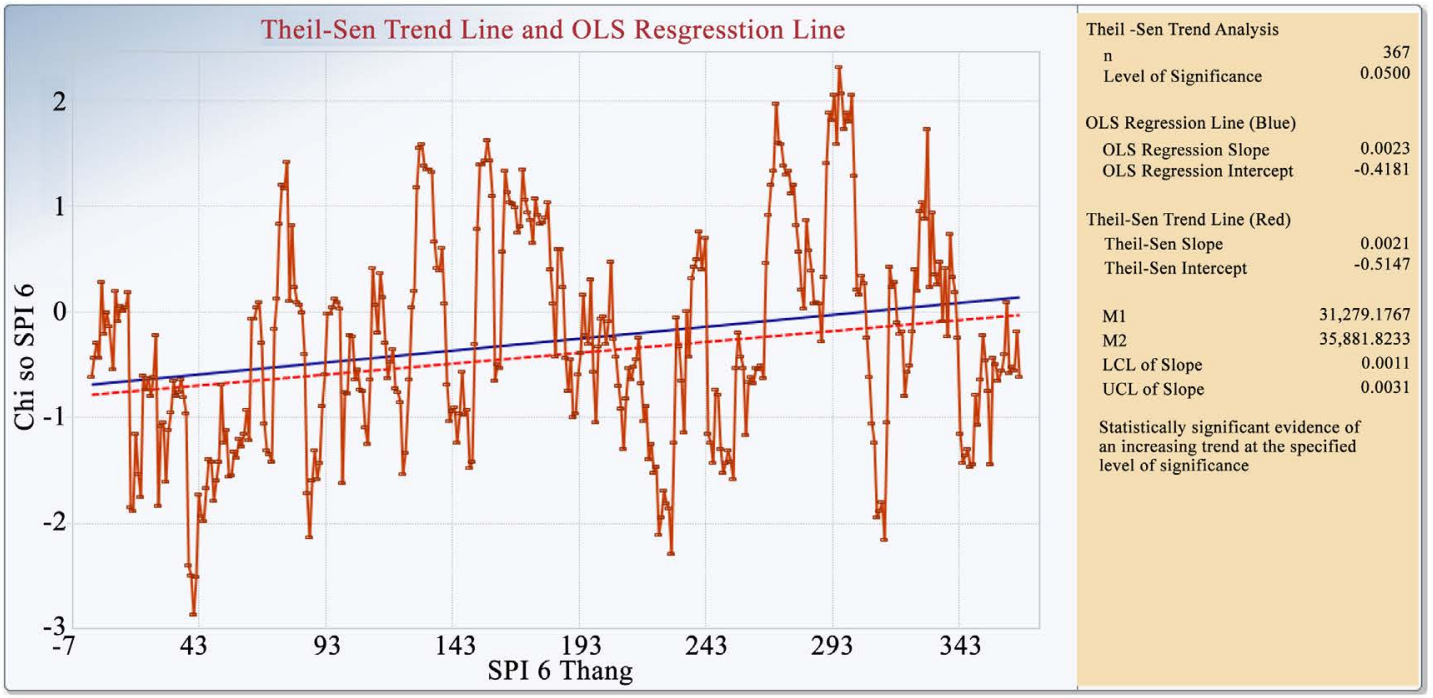

SPI 6 month - station - Ba Thap 


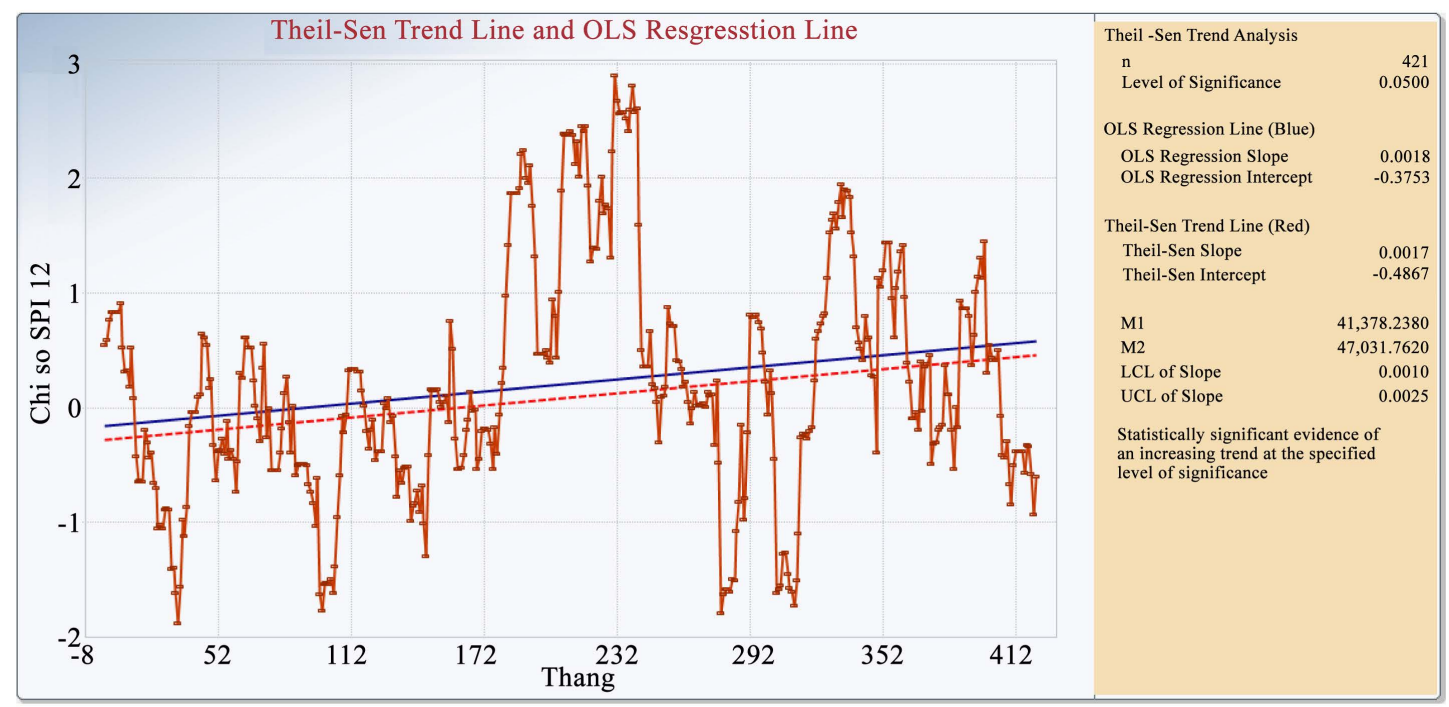

SPI 12 month - station - Tan My

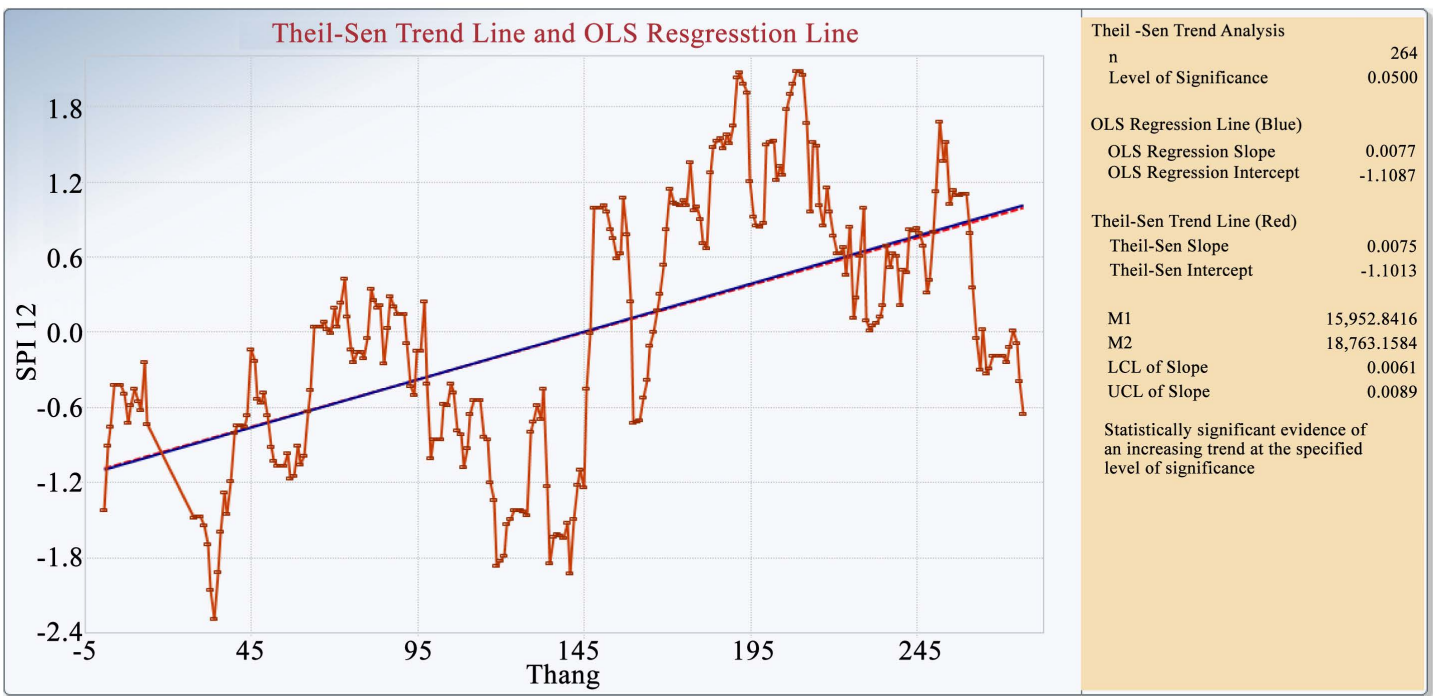

SPI 12 month - station - Song Pha

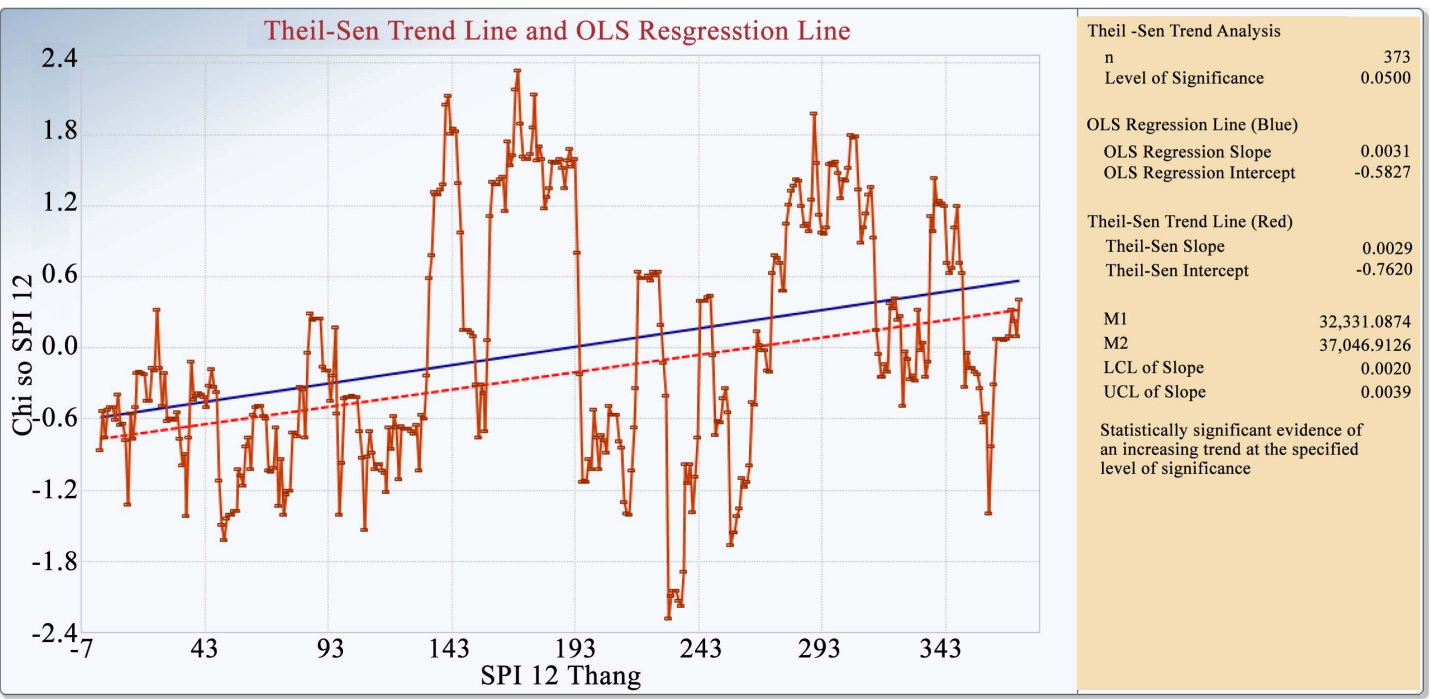

SPI 12 month - station - Quan The 


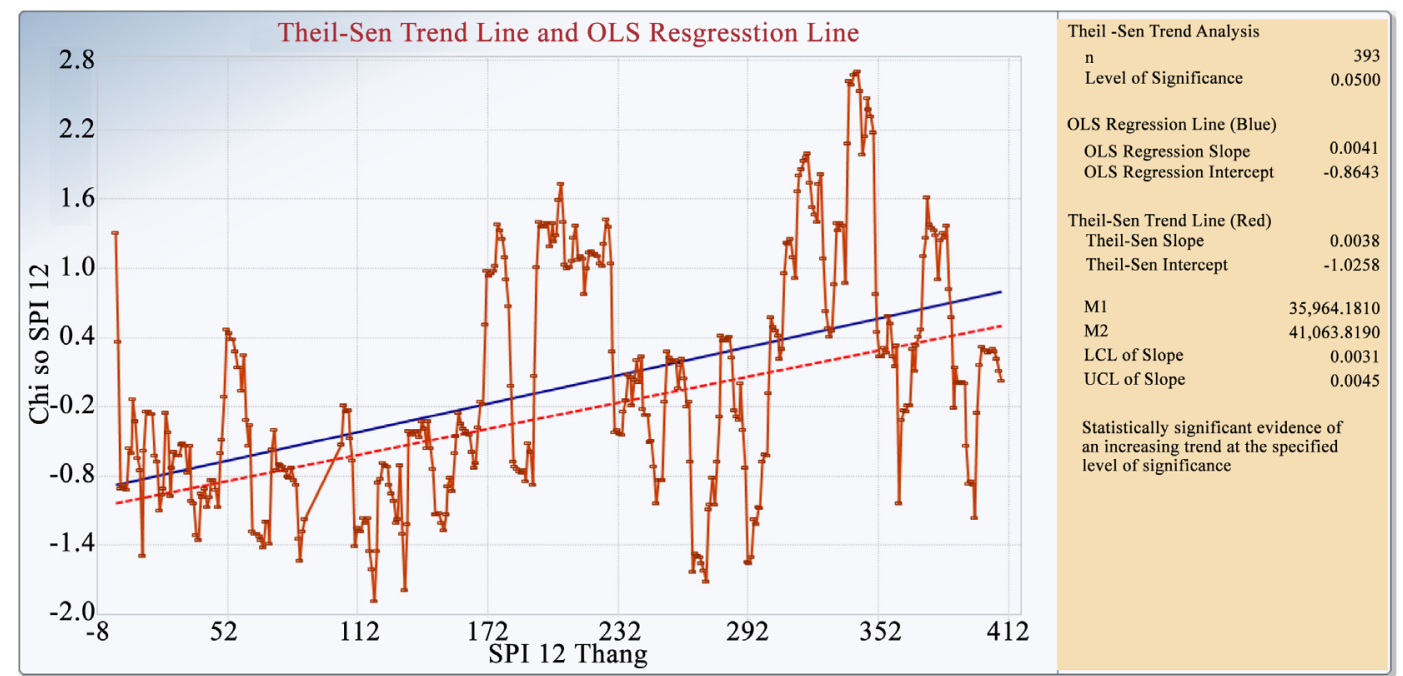

SPI 12 month - station - Phan Rang

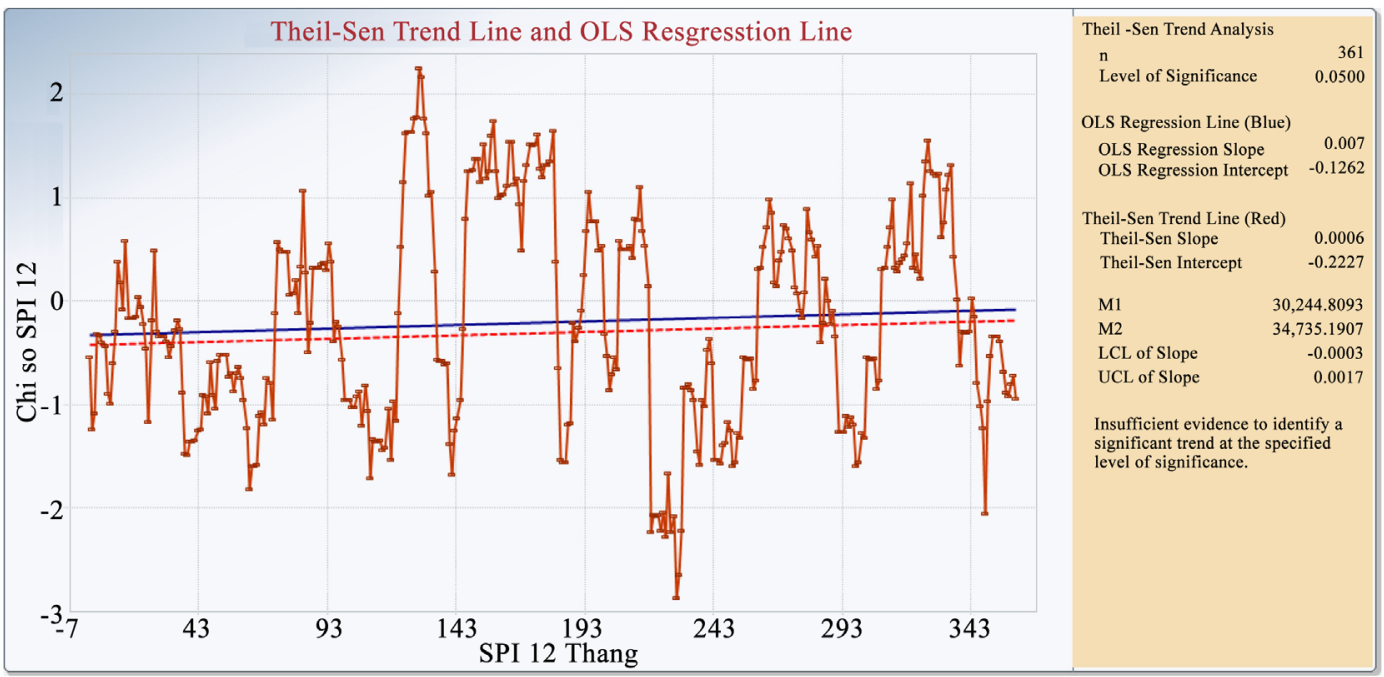

SPI 12 month - station - Nhi Ha

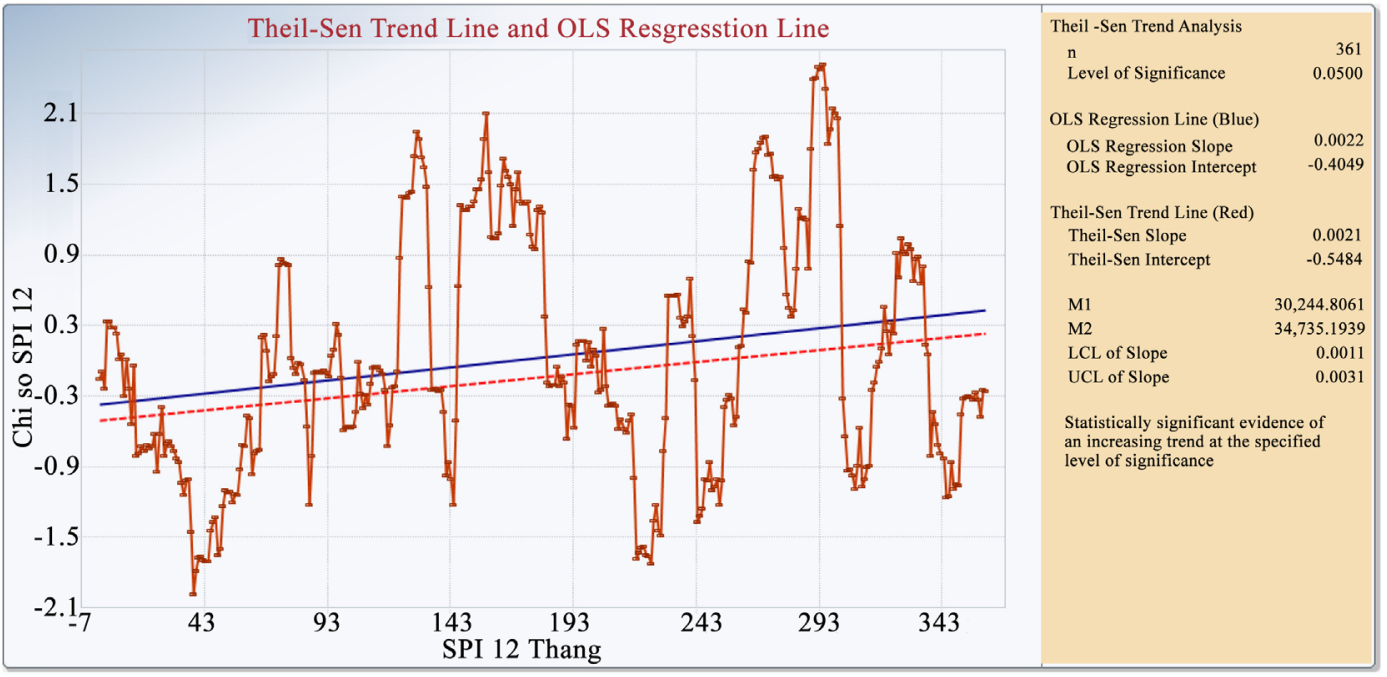

SPI 12 month - station - Ba Thap

Figure 6. Chart showing the changing trend of the SPI index. 
Table 7. Results of trend analysis at hydro-meteorological stations.

\begin{tabular}{|c|c|c|c|c|c|}
\hline \multirow{2}{*}{ Stations } & \multirow{2}{*}{$\begin{array}{c}\text { Analysis results } \\
\text { (MK and Sen's slope) }\end{array}$} & \multicolumn{4}{|c|}{ SPI } \\
\hline & & SPI 1 & SPI 3 & SPI 6 & SPI 12 \\
\hline \multirow{4}{*}{ Tan My } & $\operatorname{Var}(\mathrm{S})$ & 2997 & 2977 & 2946 & 2885 \\
\hline & $\mathrm{Z}(\mathrm{MK})$ & 1.437 & 2.6 & 3.208 & 4.756 \\
\hline & p-value & 0.0753 & 0.00466 & 0.000668 & $9.8683 \mathrm{E}-07$ \\
\hline & Sen's slope & 0.00045 & 0.00104 & 0.00132 & 0.00174 \\
\hline \multirow{4}{*}{ Song Pha } & $\operatorname{Var}(\mathrm{S})$ & 1616 & 1574 & 1533 & 1434 \\
\hline & $\mathrm{Z}(\mathrm{MK})$ & 3.596 & 5.397 & 7.425 & 9.155 \\
\hline & $\mathrm{p}$-value & $1.62 \mathrm{E}-04$ & $3.39 \mathrm{E}-08$ & $5.64 \mathrm{E}-14$ & $0.00 \mathrm{E}+00$ \\
\hline & Sen's slope & $2.11 \mathrm{E}-03$ & 0.00394 & 0.00541 & 0.00755 \\
\hline \multirow{4}{*}{ Quan The } & $\operatorname{Var}(\mathrm{S})$ & 2513 & 2494 & 2464 & 2406 \\
\hline & $\mathrm{Z}(\mathrm{MK})$ & 2.275 & 3.241 & 4.878 & 6.408 \\
\hline & p-value & $1.15 \mathrm{E}-02$ & $5.95 \mathrm{E}-04$ & $5.36 \mathrm{E}-07$ & $7.40 \mathrm{E}-11$ \\
\hline & Sen's slope & $8.24 \mathrm{E}-04$ & 0.00153 & 0.00242 & 0.00293 \\
\hline \multirow{4}{*}{ Phan Rang } & $\operatorname{Var}(\mathrm{S})$ & 2823 & 2772 & 2722 & 2602 \\
\hline & $\mathrm{Z}(\mathrm{MK})$ & 3.638 & 5.549 & 7.777 & 9.748 \\
\hline & $\mathrm{p}$-value & $1.37 \mathrm{E}-04$ & $1.44 \mathrm{E}-08$ & $3.66 \mathrm{E}-15$ & $0.00 \mathrm{E}+00$ \\
\hline & Sen's slope & $1.33 \mathrm{E}-03$ & 0.00239 & 0.00326 & 0.00379 \\
\hline \multirow{4}{*}{ Nhi Ha } & $\operatorname{Var}(\mathrm{S})$ & 2396 & 2377 & 2348 & 2291 \\
\hline & $\mathrm{Z}(\mathrm{MK})$ & 0.294 & 0.854 & 0.991 & 1.302 \\
\hline & p-value & $3.84 \mathrm{E}-01$ & $1.97 \mathrm{E}-01$ & $1.61 \mathrm{E}-01$ & $9.65 \mathrm{E}-02$ \\
\hline & Sen's slope & $0.00 \mathrm{E}+00$ & $4.25 \mathrm{E}-04$ & $5.15 \mathrm{E}-04$ & $6.46 \mathrm{E}-04$ \\
\hline \multirow{4}{*}{ Ba Thap } & $\operatorname{Var}(\mathrm{S})$ & 2396 & 2377 & 2348 & 2291 \\
\hline & Z (MK) & 2.319 & 3.699 & 4.255 & 3.938 \\
\hline & p-value & $1.02 \mathrm{E}-02$ & $1.08 \mathrm{E}-04$ & $1.05 \mathrm{E}-05$ & $4.11 \mathrm{E}-05$ \\
\hline & Sen's slope & $9.03 \mathrm{E}-04$ & $1.72 \mathrm{E}-03$ & $2.09 \mathrm{E}-03$ & $2.06 \mathrm{E}-03$ \\
\hline
\end{tabular}

SPI 1 increased by 0.0008 , SPI 3 increased by 0.00153 , SPI 6 increased by 0.000242 , and SPI 12 increased by 0.000293 .

At Phan Rang station, calculating the trend results showed that the cashew indexes have statistical significance with p-value $<0.05$ and the coefficient of standard $\mathrm{Z}$ is relatively high from 2.5 to 9.7 , and the coefficient Theil-Sen increases in the frame from 0.0013 to 0.05 (Table 7). SPI 1, SPI 3, SPI 6, and SPI 12 show a nearly equal increase trend, especially SPI 6 and SPI 12 with standard deviations of 2722, 2662, 2602, respectively. That is, the Theil-Sen slope is equally increasing with the increase of $0.0033,0.0036$, and 0.0038 , respectively.

At Nhi Ha station generally tended to increase, but the indicators were too low with the standard $\mathrm{Z}$ value from 0.19 to 1.3 , and the meager Theil-Sen ratio increased by 0.002 , and in which the SPI 1 index does not increase. 
In Ba Thap, the upward trend of the SPI indexes is clear, the Theil-Sen index from SPI 1 to SPI 12 is shallow, but the positive $Z$ value means that the SPI 1 to SPI 12 increases and increased from 0.00017 to 0.00197 corresponding. SPI 1 increased 0.000903, SPI 3 increased 0.00172, SPI 6 increased 0.00209, and SPI 12 increased 0.00206 .

\subsubsection{The Trend of Agricultural Drought}

The analysis results of the trend of changes in MI year show that the whole Ninh Thuan province tends to increase the MI index and means that the term will decrease in the future. The analysis results showed that the annual MI increased by 0.0133 per year, corresponding to the Sen's slope index of 0.0133 . The results of increasing MI in Ninh Thuan show very clearly and have very high statistical significance with $\mathrm{Z}$ is 3164 and $\mathrm{p}$-value is 0.008 .

The changing trend at $\mathrm{Ba}$ Thap, $\mathrm{Ca} \mathrm{Na}$, Nha Ho, Nhi Ha, Phan Rang, Quan The, Song Pha, and Tan My stations generally increases with different statistical significance. Comparing the increase in MI of different regions compared to MI year, the only Song Pha region is higher than the MI year (0.030 with 0.0133), while the rest areas are lower than MI. The analysis results also showed that many stations have statistically significant ( $\mathrm{p} \leq 0.05$ ) such as Phan Rang, Quan The, Song Pha, and the remaining stations are not statistically significant. In Phan Rang, the results showed that the p-value was 0.016 , with the coefficient $\mathrm{Z}>0, \mathrm{Z}$ equal to 2.144 and the Sen's slope index of 0.0063 , with the Sen's slope index showed in the Phan Rang area, the MI index would increase adding 0.0063 per year (Table 7, Figure 7(e)). In Quan The, trend analysis shows that every year the MI index increases by 0.0062 , this corresponds to the Sen's slope is 0.0062 , and the result of the MK calculation shows a positive $\mathrm{Z}$ index, with $\mathrm{Z}$ is 2.061, it illustrates drought reduction trends in Quan The area (Table 8, Figure 7(f)). Song Pha is the region with the highest increase in MI in the regions and higher than the annual MI index, with annual increases of 0.03 per year; this value corresponds to the Theil-Sen analysis is 0.0300 . The results of calculating the $\mathrm{Z}$ index of Song Pha also reflect the increasing trend of the MI index $(\mathrm{Z}>0)$ with $\mathrm{Z}$ is 2.874 (Table 8, Figure $7(\mathrm{~g})$ ).

As for the remaining stations, although the $\mathrm{p}$-value index is not in the statistical significance $(p \geq 0.05)$, it still looks to assess trends and is also considered as

Table 8. Analysis results of MK index of MI (year).

\begin{tabular}{cccccccccc}
\hline \multirow{2}{*}{$\begin{array}{c}\text { Result of MK } \\
\text { and }\end{array}$} & \multicolumn{10}{c}{ Stations } \\
\cline { 2 - 10 } Theil-Sen test & $\begin{array}{c}\text { MI } \\
\text { year }\end{array}$ & $\begin{array}{c}\text { Ba } \\
\text { Thap }\end{array}$ & $\begin{array}{c}\text { Ca } \\
\text { Na }\end{array}$ & $\begin{array}{c}\text { Nha } \\
\text { Ho }\end{array}$ & $\begin{array}{c}\text { Nhi } \\
\text { Ha }\end{array}$ & $\begin{array}{c}\text { Phan } \\
\text { Rang }\end{array}$ & $\begin{array}{c}\text { Quan } \\
\text { The }\end{array}$ & $\begin{array}{c}\text { Song } \\
\text { Pha }\end{array}$ & $\begin{array}{c}\text { Tan } \\
\text { My }\end{array}$ \\
\hline Var (S) & 58.78 & 58.76 & 58.79 & 58.81 & 58.75 & 58.78 & 58.72 & 42.79 & 58.73 \\
Z (MK) & 3.164 & 1.566 & 1.616 & 0.697 & 0.426 & 2.144 & 2.061 & 2.874 & 0.817 \\
p-value & $\mathbf{0 . 0 0 0 8}$ & 0.0587 & 0.0531 & 0.243 & 0.335 & $\mathbf{0 . 0 1 6}$ & $\mathbf{0 . 0 1 9 7}$ & $\mathbf{0 . 0 0 2 0 3}$ & 0.207 \\
Sen's slope & $\mathbf{0 . 0 1 3 3}$ & $\mathbf{0 . 0 0 6 3}$ & $\mathbf{0 . 0 0 5}$ & $\mathbf{0 . 0 0 2 2}$ & $\mathbf{0 . 0 0 1 4}$ & $\mathbf{0 . 0 0 6 3}$ & $\mathbf{0 . 0 0 6 2}$ & $\mathbf{0 . 0 3 0 0}$ & $\mathbf{0 . 0 0 3 2}$ \\
\hline
\end{tabular}




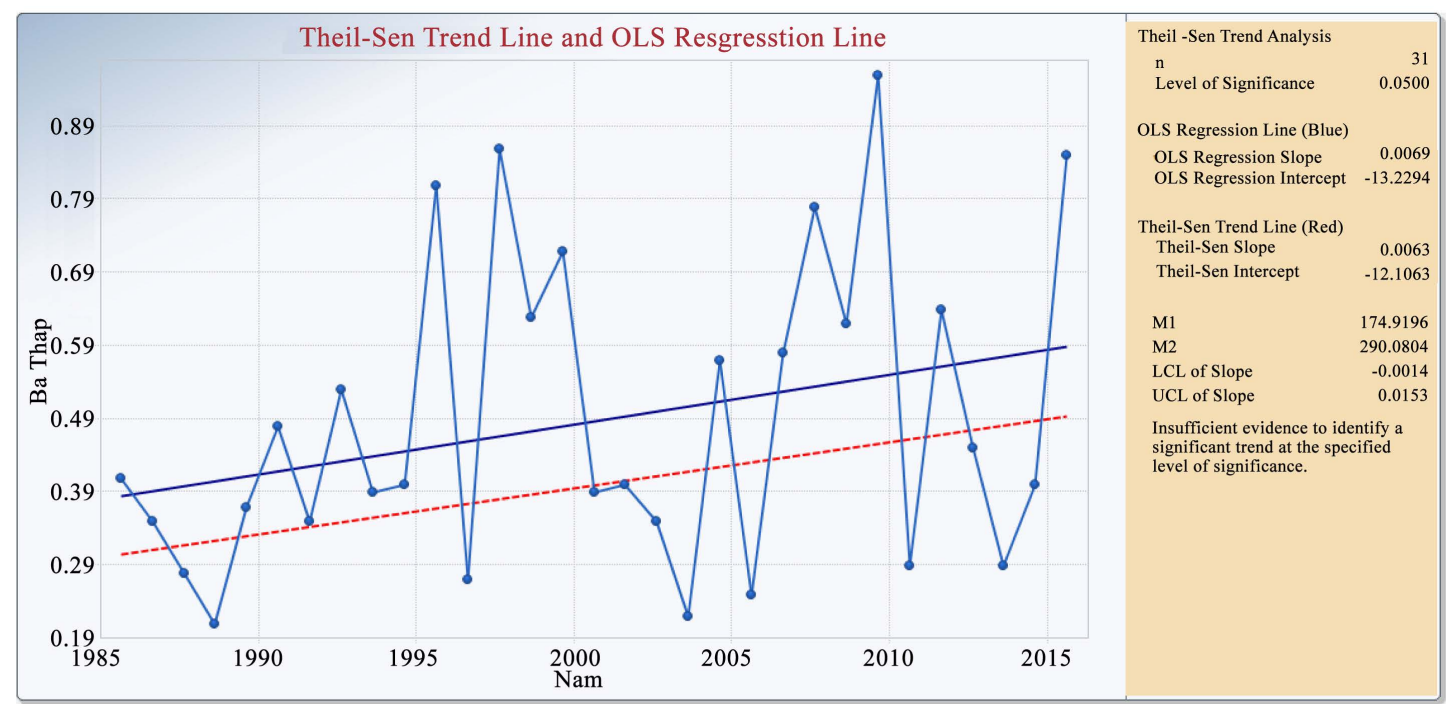

(a)

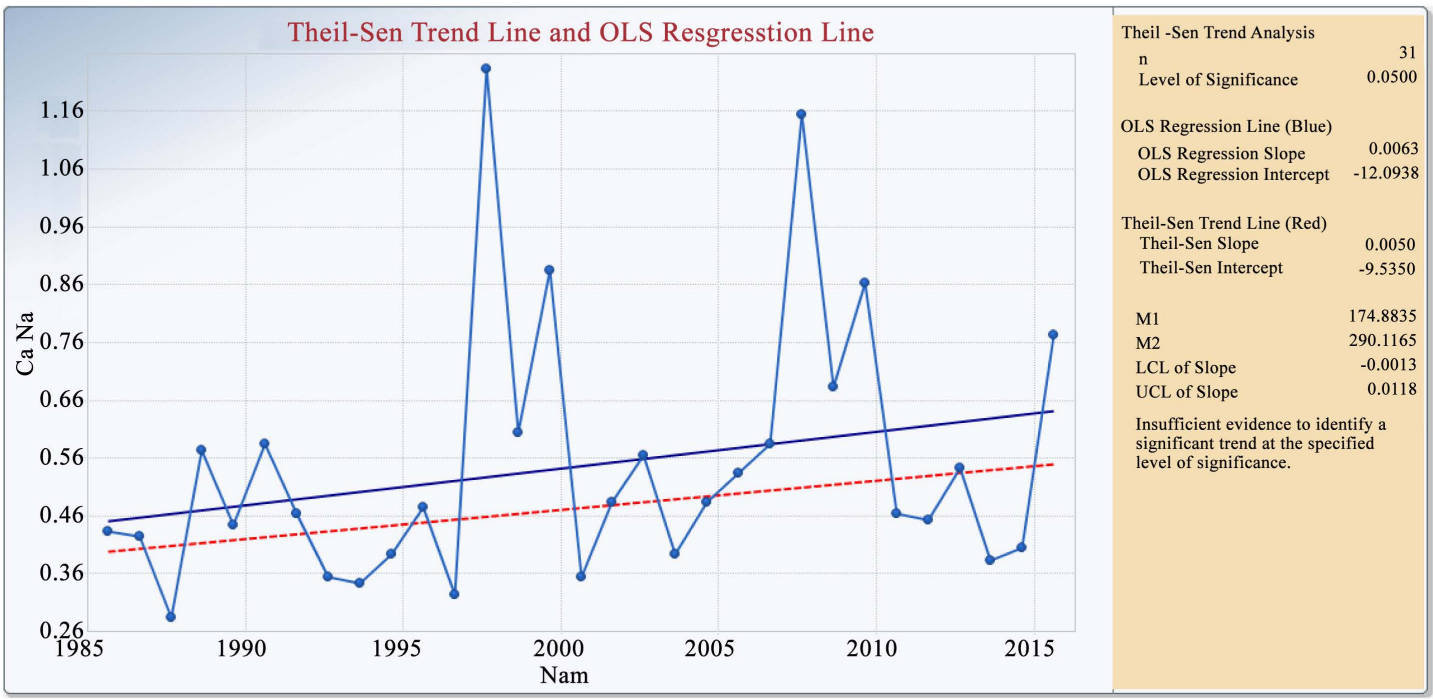

(b)

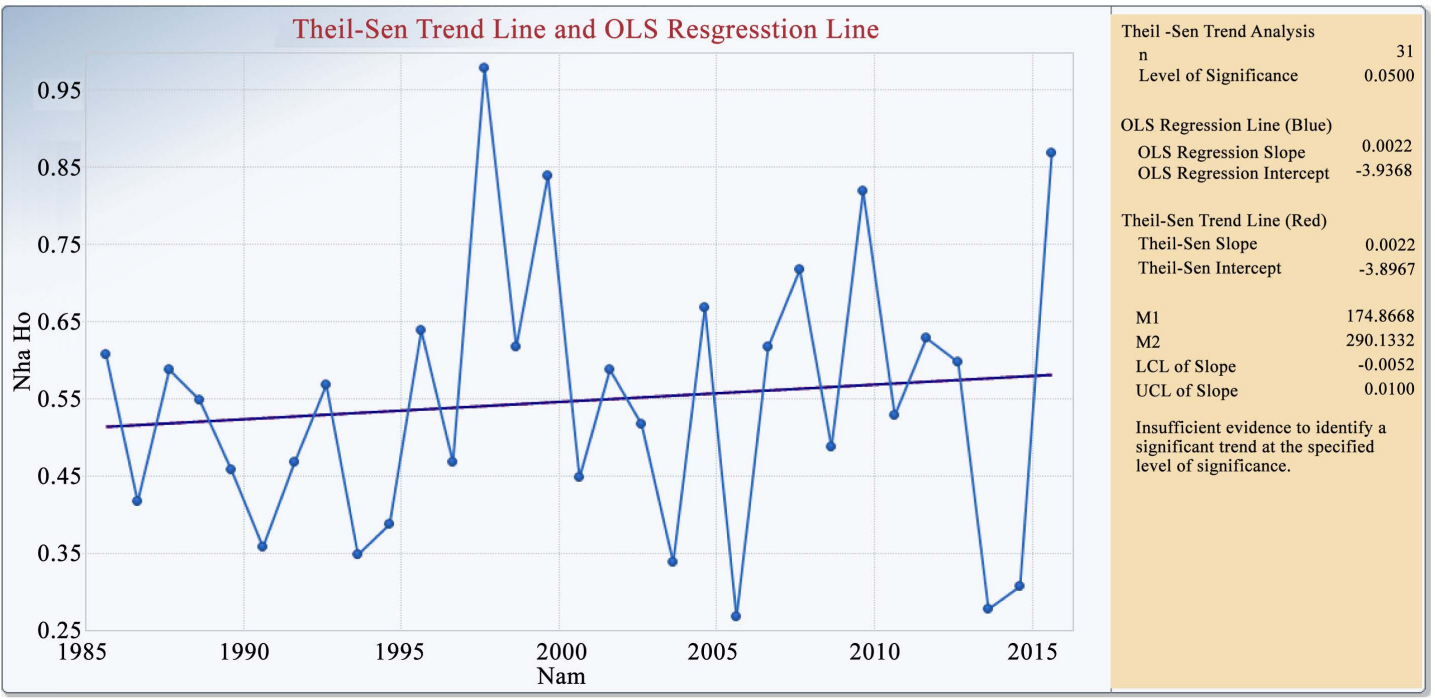

(c) 


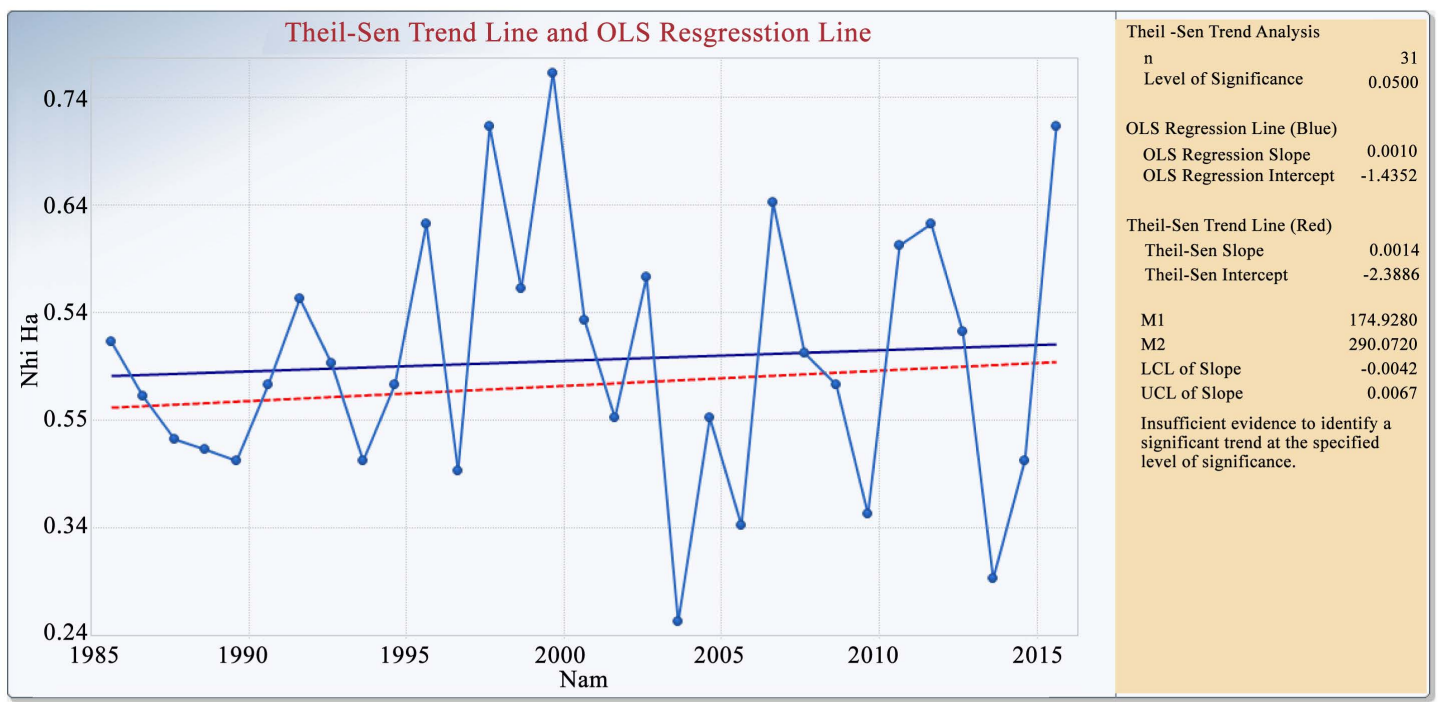

(d)

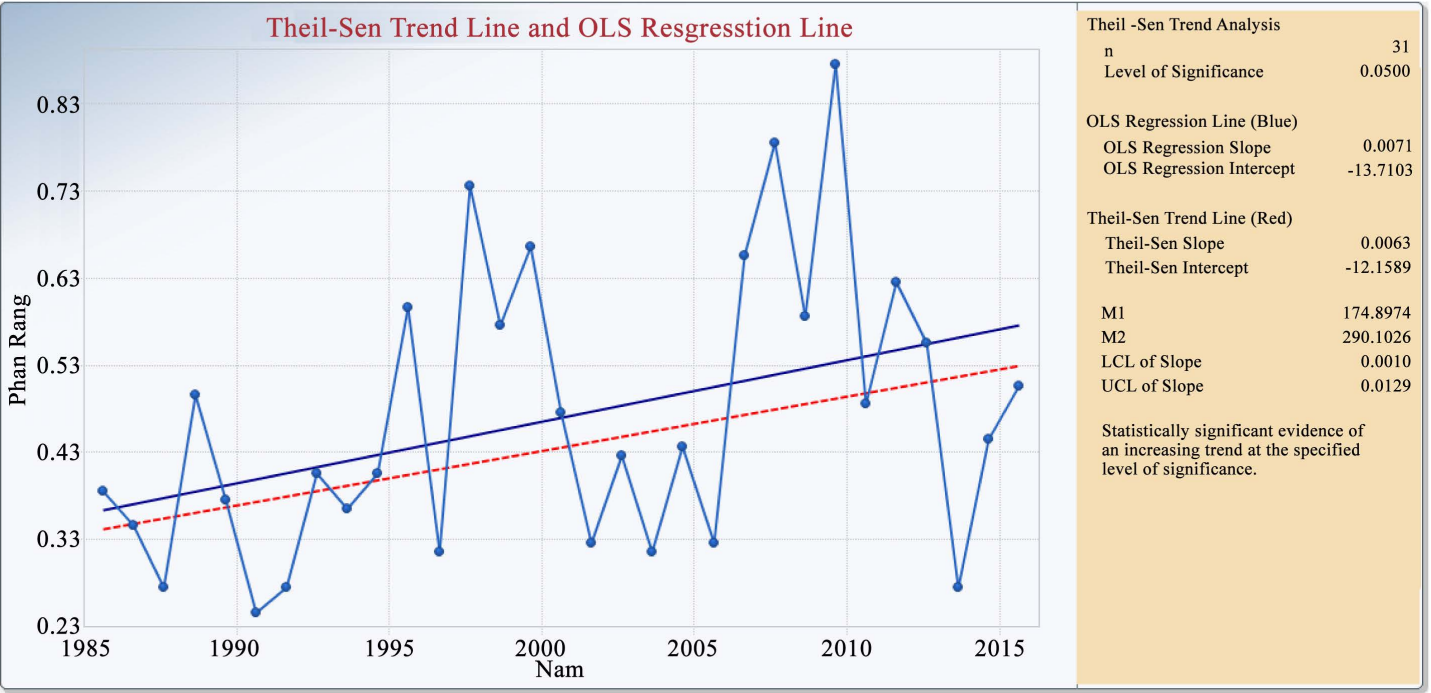

(e)

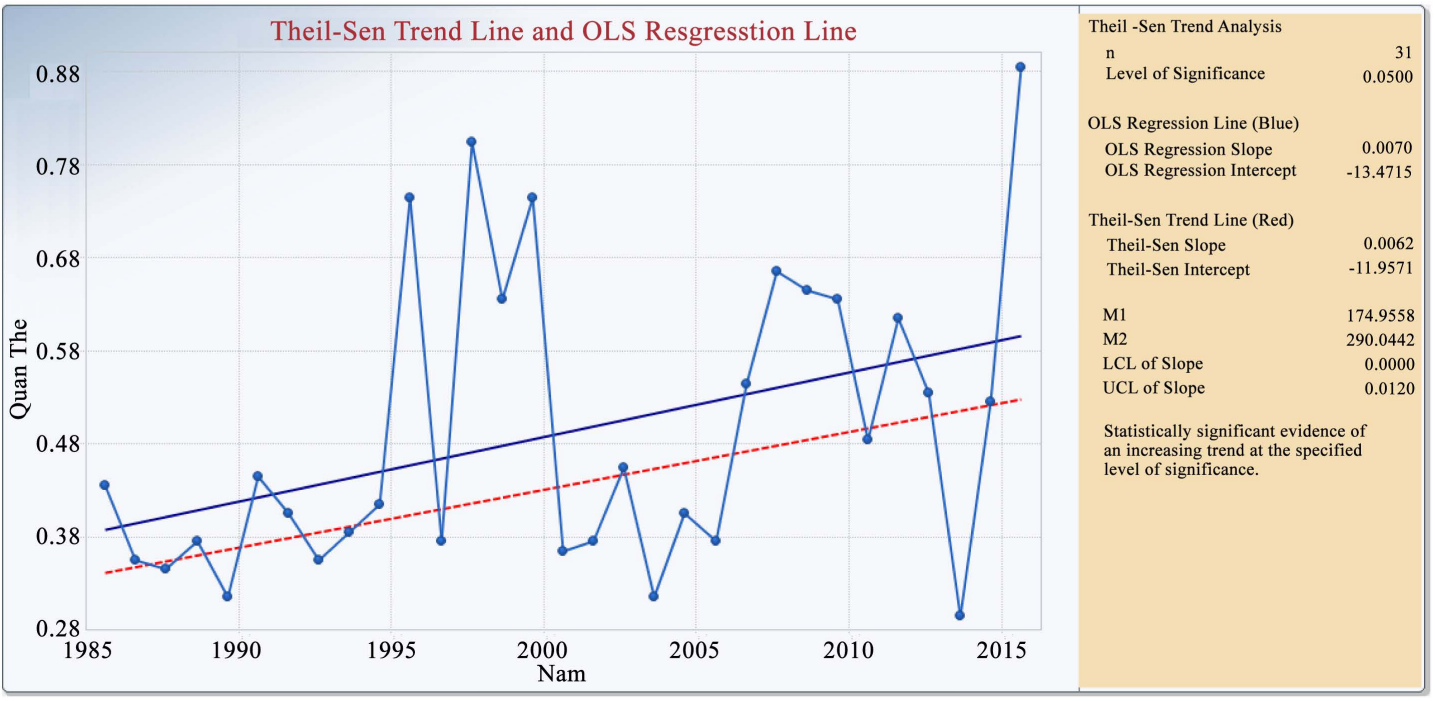

(f) 


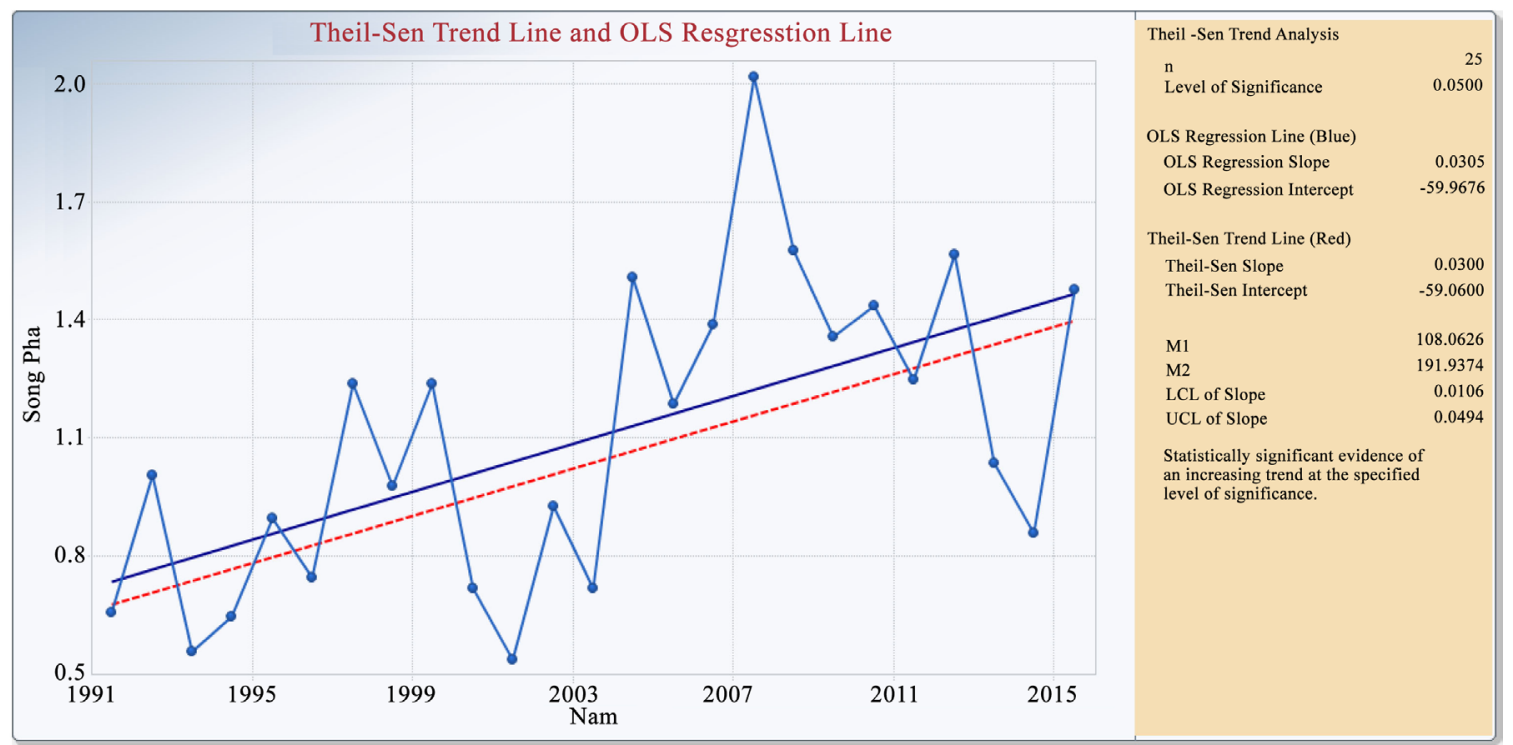

(g)

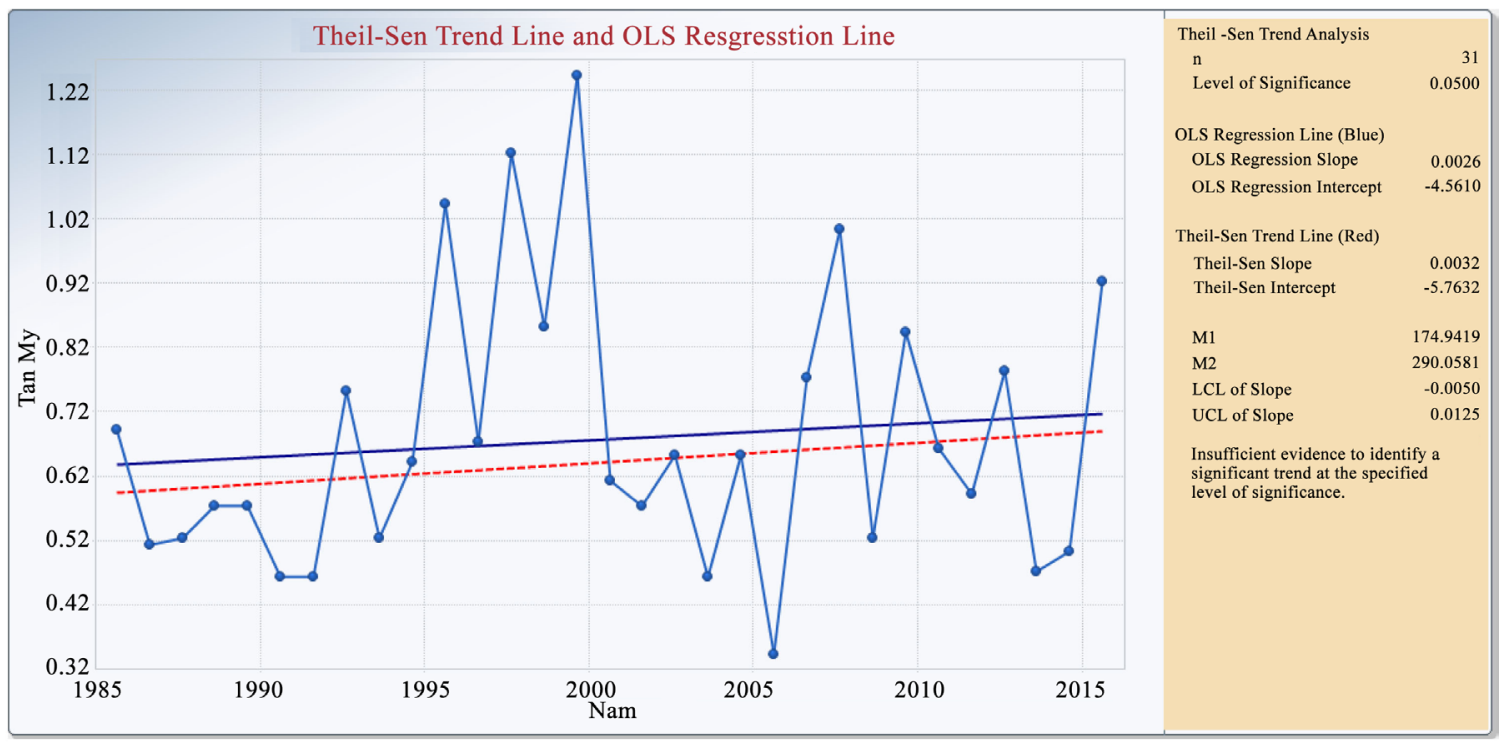

(h)

Figure 7. The trend of MI index changes at the stations. (a) Ba Thap Station; (b) Ca Na Station; (c) Nha Ho Station; (d) Nhi Ha Station; (e) Phan Rang Station; (f) Quan The Station; (g) Song Pha Station; (h) Tan My Station.

a basis for analyzing and forecasting in the future. At Ba Thap, $\mathrm{Ca} \mathrm{Na}$, Nha Ho, Nhi Ha, and Tan My stations, the p-value ranged from 0.06 to 0.20 , the $\mathrm{Z}$ index was positive $1.566,1.616,0.697,0.426$, and 0.817 , respectively; The increase in MI index of the stations ranged from 0.001 to 0.006 corresponding to the analysis index Theil-Sen of the station's Ba Thap, $\mathrm{Ca} \mathrm{Na}$, Nha Ho, Nhi Ha, and Tan My were $0.006,0.005,0.002,0.001$, and 0.003 (Table 8, Figures $7(\mathrm{a})-(\mathrm{d})$ and Figure $7(\mathrm{~h})$ ).

The study also showed that the MI index by month tends to increase, reducing the risk of drought in Ninh Thuan province. Analyzing the trend of changes in the MI index by month, the results showed eleven months of increasing and one 
month of decreasing. Table 9 showed that during the year from January to August, the MI index increased, September tended to decrease, and October to December increases (Table 9). Based on the significance level, in 12 months, only January, February, May, and July are statistically significant. The remaining months are not statistically significant but are still used to evaluate trends. Specifically, according to Table 8, the MI index in September decreased by the standard value $Z<0$ equal to -0.221 with the Sen slope of -0.003 , corresponding to an increase in September with an increase of 0.003 per year. The standard $Z$ value is always optimistic in the remaining months, meaning that the drought will decrease in the months from October to August of the following year. The month with the most robust increasing trend in November with a high standard deviation of 58.8, a standard $Z$ value of 1037, and a Sen slope of 0.021 , indicating that each year in November, the MI index increases by 0.02 and the drought agriculture tends to decrease (Table 9).

\subsection{Forecasting the Trend of Changing the SPI and MI Index}

\subsubsection{Trend of Change SPI to 2100}

Analysis and compared the values of SPI 1, SPI 3, SPI 6, and SPI 12 tenses, SPI 12 increased more with an average increase of 0.006 per year, while the lowest is SPI 3 with 0.0001 per year. Specifically, SPI 1 month with an increase of 0.003 per year, by 2035 , it will increase by 0.063 , and by the end of 2100 , it will increase by 0.3 ; SPI in 3 months with meager growth rate increases by 0.002 by 2035 and by 2100 by 0.008 . The average increase of SPI 6 is 0.0002 ; in 2035, it will increase to 0.004 and about 0.02 in 2100 . SPI 12 has an increase of 0.006 will increase to 0.12 by 2035 , and by the end of the 21 st century, it will increase more than 0.5 . Considering the SPI index taking the 2016 standard year, the forecast results based on the changing trend of Theil-Sen coefficient, the results of calculating the indexes from 2016 to 2100 are as follows: SPI index in 1 month of 2016 is -0.32 to 2035 decreases to -0.26 in $2035,-0.22$ in $2050,-0.14$ in 2075 and -0.68 in 2100. SPI 3, SPI 6 tends to decrease, but not significantly; SPI 3 in 2016 is -0.38 to the end of the decade of -0.40 , SPI 6 of 2016 was -0.27 to the end of 2100 is -0.25 . The SPI 12 shows that the drought index is increasing the SPI 12 , tends to decrease from -0.08 in 2016 to 2100 , increasing to 0.42 (Table 10).

Table 9. Analysis results of MK index of MI (Month).

\begin{tabular}{|c|c|c|c|c|c|c|c|c|c|c|c|c|}
\hline \multirow{2}{*}{$\begin{array}{c}\text { Test } \\
\text { results }\end{array}$} & \multicolumn{12}{|c|}{ Month } \\
\hline & 1 & 2 & 3 & 4 & 5 & 6 & 7 & 8 & 9 & 10 & 11 & 12 \\
\hline $\operatorname{Var}(\mathrm{S})$ & 55.8 & 52.4 & 58.2 & 58.7 & 58.8 & 58.8 & 58.8 & 58.8 & 58.8 & 58.8 & 58.8 & 58.7 \\
\hline $\mathrm{Z}(\mathrm{MK})$ & 2.006 & 1.718 & 0.928 & 1.278 & 2.092 & 1.004 & 3.299 & 1.395 & -0.221 & 1.428 & 1.037 & 0.766 \\
\hline $\mathrm{p}$-value & 0.022 & 0.043 & 0.177 & 0.101 & 0.018 & 0.158 & 0.000 & 0.082 & 0.413 & 0.077 & 0.150 & 0.222 \\
\hline $\begin{array}{l}\text { Sen's } \\
\text { slope }\end{array}$ & 0.001 & 0.000 & 0.001 & 0.003 & 0.013 & 0.004 & 0.012 & 0.006 & -0.003 & 0.020 & 0.021 & 0.008 \\
\hline
\end{tabular}




\subsubsection{The Trend of Change MI to 2100}

The results estimate the trend of changing agricultural drought in Ninh Thuan province through increased MI in each year based on the Sen's slope trend calculation results. The trend estimation results showed that the period's MI index increased to the end of 2100 from severe drought to a limited amount of drought. The MI index in the calculated period was 0.66, with an increase according to Theil-Sen's calculation. 0.013 per year to 2035 the MI index is 0.93 , 2050 is $1.13,2075$ is 1.46 , and by 2100 it is 1.79 .

Based on the results of calculating MK and Sen's slope index, we can predict the trend of changes in MI indicators in the future (Table 11). The forecast results show that the MI index increases over the months, meaning that the agricultural drought tends to decrease. Forecasts are based on 2016 to forecast for $2035,2050,2075$, and 2100. The forecast results show that there are only a few months with a downward trend of April, May, July, August, and December. The remaining months, droughts are almost unchanged until the end of the 21st century. Compared to 2016, January and February, and March are at severe droughts until 2035 and 2050, 2075 and 2100 unchanged drought remained at severe drought. April and May's droughts tended to decrease from severe drought to severe drought in April and severe drought in May (Table 11).

Table 10. Forecasts of SPI indicators is bases on the results of Sen's slope analysis.

\begin{tabular}{cccccccccccc}
\hline & \multicolumn{2}{c}{2016} & \multicolumn{2}{c}{2035} & \multicolumn{2}{c}{2050} & \multicolumn{2}{c}{2075} & \multicolumn{2}{c}{2100} \\
\cline { 2 - 11 } SPI/Year & $\begin{array}{c}\text { Sen's } \\
\text { slope }\end{array}$ & SPI & $\begin{array}{l}\text { Sen's } \\
\text { slope }\end{array}$ & SPI & $\begin{array}{l}\text { Sen's } \\
\text { slope }\end{array}$ & SPI & $\begin{array}{l}\text { Sen's } \\
\text { slope }\end{array}$ & SPI & $\begin{array}{l}\text { Sen's } \\
\text { slope }\end{array}$ & SPI \\
\hline SPI 1 & 0.0030 & -0.320 & 0.063 & -0.257 & 0.105 & -0.215 & 0.18 & -0.140 & 0.252 & -0.068 \\
SPI 3 & 0.0001 & -0.380 & 0.002 & -0.378 & 0.004 & -0.377 & 0.006 & -0.374 & 0.008 & -0.372 \\
SPI 6 & 0.0002 & -0.270 & 0.004 & -0.266 & 0.007 & -0.263 & 0.012 & -0.258 & 0.017 & -0.253 \\
SPI 12 & 0.0060 & -0.080 & 0.120 & 0.040 & 0.210 & 0.130 & 0.360 & 0.280 & 0.504 & 0.424 \\
\hline
\end{tabular}

Table 11. Predict the MI variable to the end of the 21st century through the Sen's slope index.

\begin{tabular}{cccccccccccc}
\hline \multirow{2}{*}{ Content } & \multicolumn{7}{c}{ Year: 2016} & \multicolumn{7}{c}{ Trend of drought } \\
\cline { 2 - 11 } & MI & Level & 2035 & Level & 2050 & Level & 2075 & Level & 2100 & Level \\
\hline Year & 0.66 & 1 & 0.93 & 2 & 1.13 & 3 & 1.46 & 3 & 1.79 & 3 \\
\hline 1 & 0.08 & 1 & 0.1 & 1 & 0.11 & 1 & 0.13 & 1 & 0.15 & 1 \\
2 & 0.02 & 1 & 0.02 & 1 & 0.02 & 1 & 0.02 & 1 & 0.02 & 1 \\
3 & 0.11 & 1 & 0.12 & 1 & 0.13 & 1 & 0.14 & 1 & 0.15 & 1 \\
4 & 0.18 & 1 & 0.24 & 1 & 0.28 & 1 & 0.35 & 1 & 0.42 & 2 \\
5 & 0.5 & 2 & 0.75 & 3 & 0.94 & 3 & 1.25 & 4 & 1.56 & 4 \\
6 & 0.44 & 2 & 0.51 & 2 & 0.56 & 2 & 0.65 & 2 & 0.74 & 2 \\
7 & 0.44 & 2 & 0.67 & 2 & 0.85 & 3 & 1.14 & 3 & 1.43 & 4 \\
8 & 0.43 & 2 & 0.55 & 2 & 0.64 & 2 & 0.78 & 2 & 0.93 & 3 \\
9 & 1.18 & 3 & 1.13 & 4 & 1.09 & 3 & 1.03 & 3 & 0.97 & 3 \\
10 & 1.42 & 4 & 1.82 & 4 & 2.12 & 4 & 2.62 & 4 & 3.12 & 4 \\
11 & 1.29 & 4 & 1.72 & 4 & 2.04 & 4 & 2.57 & 4 & 3.1 & 4 \\
12 & 0.76 & 2 & 0.92 & 3 & 1.05 & 3 & 1.25 & 4 & 1.46 & 4 \\
\hline
\end{tabular}

Note: 1: Extremely drought; 2: Severely drought; 3: Significantly drought; 4: Lessly drought. 


\section{Conclusion}

The study used SPI and MI indicators to study the drought characteristics in Ninh Thuan province and used MK and Sen's slope analysis to analyze SPI and MI indicators' variation. The meteorological drought (SPI) and agricultural drought (MI) in the Ninh Thuan area showed a difference in the drought magnitude and intensity. Meteorological drought with indicators SPI 1, 3, 6, and 12 shows the occurrence of many extreme droughts and severe droughts. In agricultural drought, mainly severe drought and significant droughts appear in the average $\mathrm{AI}$ index of the severe drought which is -0.70 .

Analyzing the trend of changing two indexes, namely meteorological drought and agriculture drought, has similarities with the present and future downward trend. For the meteorological drought, the SPI tends to increase, which means that the meteorological term tends to decrease next time. In which areas of Phan Rang, Song Pha, Quan The, and Ba Thap tend to increase very clearly, Tam My and Nhi Ha tend to increase very low. With the agricultural drought, the average MI results per year increased by 0.013 per year, with the Song Pha station tending to increase the highest with 0.03 per year and the lowest is Nhi Ha with 0.001 per year.

Meteorological drought forecast results show that by the end of the 21st century, the index SPI 1, 3, 6, and 12 tends to decrease compared to 2016. With SPI 1 being -0.68 , SPI 3 is -0.40 , SPI 6 is -0.25 , and SPI 12 is 0.42 . Along with that is the forecast that the MI index will increase 0.013 per year to 2035, the MI index is 0.93 , in 2050 is 1.13 , in 2075 is 1.46 , and by 2100 it is 1.79 .

The research results show the vital role of non-parametric analysis in analyzing and assessing changing environmental field trends. MK and Sen's slope analysis is currently a useful tool for many studies related to predicting change trends related to meteorology and hydrology. In the field of drought research, the application of MK and Sen's slope will be the foundation for policymakers, environmental resources management agencies, researchers ... to develop and research solutions for adapting and mitigating the impacts of drought on socio-economic in the present and the future.

\section{Conflicts of Interest}

The authors declare no conflicts of interest regarding the publication of this paper.

\section{References}

Abares (2012). Drought in Australia: Context, Policy, and Management (No. 43282). Australian Bureau of Agricultural and Resource Economics and Sciences report to client (GHD Pty. Ltd.) prepared for the Australia China Environment Development Partnership.

Adhikari, A., Mainali, K. P., Rangwala, I., \& Hansen, A. J. (2019). Various Measures of Potential Evapotranspiration Have Species-Specific Impact on Species Distribution Models. Ecological Modelling, 414, Article ID: 108836. 
https://doi.org/10.1016/j.ecolmodel.2019.108836

AghaKouchak, A. (2014). A Baseline Probabilistic Drought Forecasting Framework Using Standardized Soil Moisture Index: Application to the 2012 United States Drought. $H y-$ drology and Earth System Sciences, 18, 2485-2492.

https://doi.org/10.5194/hess-18-2485-2014

Ahmed, S. I., Rudra, R., Dickinson, T., \& Ahmed, M. (2014). Trend and Periodicity of Temperature Time Series in Ontario. American Journal of Climate Change, 3, 272-288. https://doi.org/10.4236/ajcc.2014.33026

Allaby, M., Garratt, R., \& Allaby, M. (2003). Droughts (Rev. ed.). Facts on File.

AMS (1997). Meteorological Drought-Policy Statement. Bulletin of the American Meteorological Society, 78, 847-849. https://doi.org/10.1175/1520-0477-78.5.847

Azad, A. S., Hasan, Md. K., Rahman, M. A. I., Rahman, Md. M., \& Shahriar, N. (2014). Exploring the Behavior and Changing Trends of Rainfall and Temperature Using Statistical Computing Techniques. In T. Islam, P. K. Srivastava, M. Gupta, X. Zhu, \& S. Mukherjee (Eds.), Computational Intelligence Techniques in Earth and Environmental Sciences (pp. 53-78). Dordrecht: Springer.

https://doi.org/10.1007/978-94-017-8642-3 3

Bayazıt, Y., Bakış, R., \& Koç, C. (2019). Mapping of Stream Flow Trends in Porsuk Basin Using GIS Environment. Journal of Geoscience and Environment Protection, 7, 58-66. https://doi.org/10.4236/gep.2019.79005

Bera, S. (2017). Trend Analysis of Rainfall in Ganga Basin, India during 1901-2000. American Journal of Climate Change, 6, 116-131. https://doi.org/10.4236/ajcc.2017.61007

Bhuyan, Md. D. I., Islam, Md. M., \& Bhuiyan, Md. E. K. (2018). A Trend Analysis of Temperature and Rainfall to Predict Climate Change for Northwestern Region of Bangladesh. American Journal of Climate Change, 7, 115-134. https://doi.org/10.4236/ajcc.2018.72009

Blain, G. C. (2012). Revisiting the Probabilistic Definition of Drought: Strengths, Limitations and an Agrometeorological Adaptation. Bragantia, 71, 132-141. https://doi.org/10.1590/S0006-87052012000100019

Bordi, I., \& Sutera, A. (2007). Drought Monitoring and Forecasting at Large Scale. In G. Rossi, T. Vega, \& B. Bonaccorso (Eds.), Methods and Tools for Drought Analysis and Management (pp. 3-27). Dordrecht: Springer. https://doi.org/10.1007/978-1-4020-5924-7 1

Brewer, M. J., \& Heim Jr., R. R. (2011). The Global Drought Monitor Portal. http://digitalcommons.unl.edu/droughtfacpub/55/

Cardoso, L. F. N., Silva, W. L., \& da Silva, M. G. A. J. (2016). Long-Term Trends in Near-Surface Wind Speed over the Southern Hemisphere: A Preliminary Analysis. International Journal of Geosciences, 7, 938-943. https://doi.org/10.4236/ijg.2016.77070

Chatterjee, K., Bandyopadhyay, A., Ghosh, A., \& Kar, S. (2015). Assessment of Environmental Factors Causing Wetland Degradation, Using Fuzzy Analytic Network Process: A case Study on Keoladeo National Park, India. Ecological Modelling, 316, 1-13. https://doi.org/10.1016/j.ecolmodel.2015.07.029

Cooley, H., Donnelly, K., Phurisamban, R., \& Subramanian, M. (2015). Impacts of California's Ongoing Drought: Agriculture. Oakland, CA: Pacific Institute. https://www.shrm.org/ResourcesAndTools/legal-and-compliance/state-and-local-upda tes/Documents/ImpactsOnCaliforniaDrought-Ag.pdf

Correia, F. N. (2007). Water Scarcity and Drought a Priority of the Portuguese Presiden- 
cy. Ministério do Ambiente, do ordenamento do território e do desenvolvimento regional.

CRED (2006). CRED Crunch December 2006. Centre for Research on the Epidemiology of Disasters. Belgium.

Dai, A., Trenberth, K. E., \& Qian, T. (2004). A Global Dataset of Palmer Drought Severity Index for 1870-2002: Relationship with Soil Moisture and Effects of Surface Warming. Journal of Hydrometeorology, 5, 1117-1130. https://doi.org/10.1175/JHM-386.1

Ding, Y., Hayes, M. J., \& Widhalm, M. (2010). Measuring Economic Impacts of Drought: A Review and Discussion. Disaster Prevention and Management: An International Journal, 20, 434-446. https://doi.org/10.1108/09653561111161752

Djaman, K., Koudahe, K., \& Ganyo, K. K. (2017). Trend Analysis in Annual and Monthly Pan Evaporation and Pan Coefficient in the Context of Climate Change in Togo. Journal of Geoscience and Environment Protection, 5, 41-56. https://doi.org/10.4236/gep.2017.512003

Doan Van Diem, \& Tran Danh Thin (2007). Assessment of Drought Impacts and Some Keeping Soil Moisture Measures on Winter Maize in Midland Area of Northern Vietnam. VNU Journal of Science: Natural Sciences and Technology, 23, 91-98.

Domeisen, N. (1995). Disasters: Threat to Social Development. STOP Disasters, The IDNDR Magazine No. 23, Geneva, Switzerland: IDNDR Secretariat.

DrinC (2019). Drought Indices Calculator (1.7). Computer Software. https://drought-software.com

EPA (2016). ProUCL Software 5.1.00(5.1). https://www.epa.gov/land-research/proucl-software

Ernest, S., Nduganda, A. R., \& Kashaigili, J. J. (2017). Urban Climate Analysis with Remote Sensing and Climate Observations: A Case of Morogoro Municipality in Tanzania. Advances in Remote Sensing, 6, 120-131.

https://doi.org/10.4236/ars.2017.62009

Esfahanian, E., Nejadhashemi, A. P., Abouali, M., Adhikari, U., Zhang, Z., Daneshvar, F., \& Herman, M. R. (2017). Development and Evaluation of a Comprehensive Drought Index. Journal of Environmental Management, 185, 31-43. https://doi.org/10.1016/j.jenvman.2016.10.050

FAO (1978). Report on the Agro-Ecological Zones Project. Vol. 1: Methodology and Result for Africa. World Soil Resources Report 48/1, FAO.

Gillette, H. P. (1950). A Creeping Drought under Way. Water and Sewage Works, 104-105.

Govorushko, S. M. (2012). Natural Processes and Human Impacts. Dordrecht: Springer. https://doi.org/10.1007/978-94-007-1424-3

GSA (2006). Managing Drought: A Roadmap for Change in the United States. A conference report from Managing Drought and Water Scarcity in Vulnerable Environments, Longmont, CO, 18-20 September 2006.

Hashemi, F., \& Habibian, M. T. (1979). Limitations of Temperature-Based Methods in Estimating Crop Evapotranspiration in Arid-Zone Agricultural Development Projects. Agricultural Meteorology, 20, 237-247. https://doi.org/10.1016/0002-1571(79)90025-6

Helsel, D. R., \& Hirsch, R. M. (1992). Statistical Methods in Water Resources (Vol. 49, pp. iii-xvi). Amsterdam: Elsevier Science Ltd.

Henry, B., McKeon, G., Syktus, J., Carter, J., Day, K., \& Rayner, D. (2007). Climate Variability, Climate Change and Land Degradation. In M. V. K. Sivakumar, \& N. Ndiang'ui (Eds.), Climate and Land Degradation (pp. 205-221). Berlin, Heidelberg: Springer. 
Herweijer, C., Seager, R., Cook, E. R., \& Emile-Geay, J. (2007). North American Droughts of the Last Millennium from a Gridded Network of Tree-Ring Data. Journal of Climate, 20, 1353-1376. https://doi.org/10.1175/JCLI4042.1

Islam, A. W. (2015). Rainy/Non-Rainy Day Pattern Analysis for North Carolina. American Journal of Climate Change, 4, 1-8. https://doi.org/10.4236/ajcc.2015.41001

Jenkins, K. L. (2011). Modelling the Economic and Social Consequences of Drought under Future Projections of Climate Change. $\mathrm{PhD}$ Thesis, Cambridge: University of Cambridge.

Jeyaseelan, A. T. (2003). Droughts \& Floods Assessment and Monitoring Using Remote Sensing and GIS. In M. V. K Sivakumar et al. (Eds.), Satellite Remote Sensing and GIS Applications in Agricultural Meteorology (Vol. 291). Geneva, Switz: World Meteorological Organisation. http://www.wamis.org/agm/pubs/agm8/Paper-14.pdf

Kendall, M. G. (1975). Rank Correlation Methods. London: Griffin.

Koba, M. (2014, September 5). Global Drought Real Threat to Lives and Economies: EXperts. CNBC.

http://www.cnbc.com/2014/09/05/global-drought-real-threat-to-lives-and-economicesexperts.html

Koudahe, K., Kayode, A. J., Samson, A. O., Adebola, A. A., \& Djaman, K. (2017). Trend Analysis in Standardized Precipitation Index and Standardized Anomaly Index in the Context of Climate Change in Southern Togo. Atmospheric and Climate Sciences, 7, 401-423. https://doi.org/10.4236/acs.2017.74030

Lake, P. S. (2011). Drought and Aquatic Ecosystems: Effects and Responses. Hoboken, NJ: Wiley-Blackwell. https://doi.org/10.1002/9781444341812

Le Thi Thu Hien (2013). Application the Normalised Difference Vegetation Index of Landsat Imagery to Assess the Desertification in Binh Thuan Province. Vietnam Journal of Earth Sciences, 35, 357-363.

Mann, H. B. (1945). Non-Parametric Tests Against Trend. Econometrica, 13, 245-259. https://doi.org/10.2307/1907187

McKee, T. B., Doesken, N. J., Kleist, J. et al. (1993). The Relationship of Drought Frequency and Duration to Time Scales. Proceedings of the 8th Conference on Applied Climatology, 17, 179-183.

Moeletsi, M. E., Walker, S., \& Hamandawana, H. (2013). Comparison of the Hargreaves and Samani Equation and the Thornthwaite Equation for Estimating Dekadal Evapotranspiration in the Free State Province, South Africa. Physics and Chemistry of the Earth, Parts $A / B / C, 66,4-15$. https://doi.org/10.1016/j.pce.2013.08.003

Murumkar, A. R., \& Arya, D. S. (2014). Trend and Periodicity Analysis in Rainfall Pattern of Nira Basin, Central India. American Journal of Climate Change, 3, 60-70. https://doi.org/10.4236/ajcc.2014.31006

Ngo Dinh Tuan, \& Ngo Le An (2016). Research on Drought Factors, Criteria, Classification in Ninh Thuan-Binh Thuan Provinces and Their Prevention and Mitigation Measures. Journal of Water Resources and Environmental Engineering, 30, 132.

Nguyễn Đinh Tuấn, Bảo Văn Tuy, \& Nguyễn Kỳ Phùng (2012). Tác động của biến đổi khí hậu đến lĩnh vực nông nghiệp ở Ninh Thuận và giải pháp tương ứng. Tạp Chí Tài Nguyên và Môi Trường, 23, pp. (In Vietnamese)

Nguyễn Đình Vượng, \& Huỳnh Ngọc Tuyên (2012). Một số giải pháp sử dụng hợp lý tài nguyên nước, phòng chống hạn hán, sa mạc hóa, thích ứng biến đổi khí hậu trên vùng đất cát ven biển Ninh Thuận. Thông Tin Khoa Học Công Nghệ Ninh Thuận, Nghiên cứu trao đổi. (In Vietnamese)

Nguyễn Hồng Trường (2008). Ửng dụng các biện pháp truyền thống và khoa học kỹ 
thuật mới nhằm khai thác, bảo vệ tài nguyên đất và nước, góp phần phòng chống hạn ở xã Phước Nam tỉnh Ninh Thuận. Tạp Chí Khí Tượng Thủy Văn, 8, 45-50. (In Vietnamese)

Nyatuame, M., \& Agodzo, S. (2017). Analysis of Extreme Rainfall Events (Drought and Flood) over Tordzie Watershed in the Volta Region of Ghana. Journal of Geoscience and Environment Protection, 5, 275-295. https://doi.org/10.4236/gep.2017.59019

Ogunrinde, A. T., Olasehinde, D. A., \& Olotu, Y. (2020). Assessing the Sensitivity of Standardized Precipitation Evapotranspiration Index to Three Potential Evapotranspiration Models in Nigeria. Scientific African, 8, e00431.

https://doi.org/10.1016/j.sciaf.2020.e00431

Okafor, G. C., Jimoh, O. D., \& Larbi, K. I. (2017). Detecting Changes in Hydro-Climatic Variables during the Last Four Decades (1975-2014) on Downstream Kaduna River Catchment, Nigeria. Atmospheric and Climate Sciences, 7, 161-175.

https://doi.org/10.4236/acs.2017.72012

Pereira, A. R., \& Paes De Camargo, Â. (1989). An Analysis of the Criticism of Thornthwaite's Equation for Estimating Potential Evapotranspiration. Agricultural and Forest Meteorology, 46, 149-157. https://doi.org/10.1016/0168-1923(89)90118-4

Pereira, A. R., \& Pruitt, W. O. (2004). Adaptation of the Thornthwaite Scheme for Estimating Daily Reference Evapotranspiration. Agricultural Water Management, 66, 251-257. https://doi.org/10.1016/j.agwat.2003.11.003

Pham Quang Vinh, \& Pham Thi Thanh Huong (2013). Assessing Agricultural Drought for Binh Thuan Province under Climate Change Scenario. Vietnam Journal of Earth Sciences, 34, 513-523.

Prud'Homme, A. (2011, July 16). Drought: A Creeping Disaster. The New York Times. http://www.nytimes.com/2011/07/17/opinion/sunday/17drought.html

Salmi, T., Määttä, A., Anttila, P., Ruoho-Airola, T., \& Amnell, T. (2002). Detecting Trends of Annual Values of Atmospheric Pollutants by the Mann-Kendall Test and Sen's Slope Estimates the Excel Template Application MAKESENS (Vol. 31). Finnish Meteorological Institute.

Sen, P. K. (1968). Estimates of the Regression Coefficient Based on Kendall's Tau. Journal of the American Statistical Association, 63, 1379-1389. https://doi.org/10.1080/01621459.1968.10480934

Svoboda, M. D., Fuchs, B. A., Poulsen, C. C., \& Nothwehr, J. R. (2015). The Drought Risk Atlas: Enhancing Decision Support for Drought Risk Management in the United States. Journal of Hydrology, 526, 274-286. https://doi.org/10.1016/j.jhydrol.2015.01.006

Tadesse, T., Haile, M., Senay, G., Wardlow, B. D., \& Knutson, C. L. (2008). The Need for Integration of Drought Monitoring Tools for Proactive Food Security Management in Sub-Saharan Africa. Natural Resources Forum, 32, 265-279. https://doi.org/10.1111/j.1477-8947.2008.00211.x

Tannehill, I. R. (1947). Drought, Its Causes and Effects. Princeton, NJ: Princeton University Press.

Thao, P. T. P., Thu, P. M., Giam, N. M., Duan, H. D., \& Long, B. H. (2018). Relationship between Drought and Rainfall Due to Tropical Cyclone and Depression in Ninh Thuan, Vietnam. Current Journal of Applied Science and Technology, 30, 1-8.

Theil, H. (1950). A Rank-Invariant Method of Linear and Polynomial Regression Analysis, Part I; Confidence Regions for the Parameters of Polynomial Regression Equations. Proceedings of the Royal Netherlands Academy of Sciences, 53, 386-392.

Thornthwaite, C. W. (1948). An Approach toward a Rational Classification of Climate. 
Geographical Review, 38, 55-94. https://doi.org/10.2307/210739

Tian, Q., Wang, Q., Zhan, C., Li, X., \& Liu, X. (2012). Analysis of Climate Change in the Coastal Zone of Eastern China, against the Background of Global Climate Change over the Last Fifty Years: Case Study of Shandong Peninsula, China. International Journal of Geosciences, 3, 379-390. https://doi.org/10.4236/ijg.2012.32042

Tigkas, D., Vangelis, H., \& Tsakiris, G. (2015). DrinC: A Software for Drought Analysis Based on Drought Indices. Earth Science Informatics, 8, 697-709. https://doi.org/10.1007/s12145-014-0178-y

Tigkas, D., Vangelis, H., \& Tsakiris, G. (2017). An Enhanced Effective Reconnaissance Drought Index for the Characterisation of Agricultural Drought. Environmental Processes, 4, 137-148. https://doi.org/10.1007/s40710-017-0219-x

Tigkas, D., Vangelis, H., \& Tsakiris, G. (2020). Implementing Crop Evapotranspiration in RDI for Farm-Level Drought Evaluation and Adaptation under Climate Change Conditions. Water Resources Management, 34, 4329-4343. https://doi.org/10.1007/s11269-020-02593-6

UN Water (2015a). Proceedings of the Regional Workshops on Capacity Development to Support National Drought Management Policies for Eastern and Southern Africa and the Near East and North Africa Regions. UN-Water Decade Programme on Capacity Development (UNW-DPC) United Nations University, Bonn, Germany: UNW-DPC.

UN Water (2015b). Synthesis: Capacity Development to Support National Drought Management Policies. UN-Water Decade Programme on Capacity Development (UNW-DPC) United Nations University, Bonn, Germany: UNW-DPC.

UNDP (2012). Drought Risk Management: Practitioner's Perspectives from Africa and Asia. United Nations Development Programme, United Nation, United Nations Office at Nairobi, Publishing Services Section, ISO 14001:2004-certifed.

UNESCO (2014). Ntegrated Drought Risk Management-DRM National Framework for Iraq: An Analysis Repo (2nd Edition SC/2014/REPORT/H/1, p. 143). Iraq: UNESCO Office. http://unesdoc.unesco.org/images/0023/002330/233093e.pdf

UNISDR (2009). Drought Risk Reduction Framework and Practices: Contributing to the Implementation of the Hyogo Framework for Action. United Nations Secretariat of the International Strategy for Disaster Reduction (UNISDR), Geneva, Switzerland, in partnership with the National Drought Mitigation Center (NDMC), University of Nebraska-Lincoln, Lincoln, Nebraska, USA.

Weltbank (Ed.) (2006). Overcoming Drought: Adaptation Strategies for Andhra Pradesh, India. World Bank.

Wilhite, D. A. (2000). Drought as a Natural Hazard: Concepts and Definitions. In D. Wilhite (Ed.), Drought: A Global Assessment (Vol. 1, pp. 3-18). London: Routledge.

Wilhite, D. A., \& Glantz, M. H. (1985). Understanding: Drought Phenomenon: The Role of Definitions. Water International, 10, 111-120. https://doi.org/10.1080/02508068508686328

Wilhite, D. A., \& Glantz, M. H. (1987). Understanding the Drought Phenomena: The Role of Definitions. In D. A. Wilhite, \& W. E. Easterling (Eds.), Planning for Drought: Towards a Reduction of Societal Vulnerability (pp. 11-27). Boulder, CO: Westview Press.

WMO (2012). Standardized Precipitation Index User Guide. World Meteorological Organization.

WMO (2014). World Meteorological Organization (WMO) and Global Water Partnership (GWP) National Drought Management Policy Guidelines: A Template for Action 
(D.A. Wilhite). Integrated Drought Management Programme (IDMP) Tools and Guidelines Series 1. World Meteorological Organization; Global Water Partnership.

Zhou, J., Wang, Y., Su, B., Wang, A., Tao, H., Zhai, J., Kundzewicz, Z. W., \& Jiang, T. (2020). Choice of Potential Evapotranspiration Formulas Influences Drought Assessment: A Case Study in China. Atmospheric Research, 242, Article ID: 104979. https://doi.org/10.1016/j.atmosres.2020.104979 